\title{
Personal Bankruptcy Reform, Credit Availability, and Financial Distress
}

\author{
Hamid Boustanifar*
}

This Version: January 2013

\begin{abstract}
Whether improving access to credit alleviates financial distress among households is the subject of intense debate. While it can mitigate financial hardship through the possibility of consumption smoothing, credit access may exacerbate distress among certain group of borrowers because of over-borrowing. Using the 2005 Bankruptcy Abuse Prevention and Consumer Protection Act (BAPCPA), I investigate the impact of consumer credit availability on households' borrowing decisions and the subsequent effect on their financial well-being. Exploiting arguably exogenous cross-state variation in the generosity of bankruptcy law (exemption limits) prior to the Act, I find that households' access to credit increased significantly more in states with higher exemption limits, where lenders were more exposed to losses from bankruptcy filings. Households with low education and those with self-reported self-control problems responded aggressively by taking on large amounts of debt and spending it mainly on apparel and recreational activities. Consequently, households' distress, as measured by their inability to repay mortgage loans as well as a significant decline of food consumption, increased substantially more among low educated households and those with self-control problems. The paper highlights the real cost of credit availability for a subgroup of vulnerable borrowers.
\end{abstract}

\footnotetext{
${ }^{*}$ Stockholm School of Economics, Finance Department, and Swedish House of Finance, Drottingatan 98, 11160 Stockholm, Sweden. Email: hamid.boustanifar@hhs.se. I would like to thank Mariassunta Giannetti and Per Strömberg for their constant help at various stages of this project. I am also grateful to Franklin Allen, Laurent Bach, Ramin Baghai, Einar Bakke (discussant), Bo Becker, Ola Bengtsson, Marieke Bos, Radha Gopalan, Michael Halling, Jungsuk Han, Bige Kahraman, Pete Kyle, Ariell Reshef, Michael Simkovic, Paolo Sodini, David Strömberg, Anjan Thakor and Ulf von Lilienfeld-Toal, and seminar participants at Amsterdam Business School, Bonn University, IIES-Institute for International Economic Studies, National University of Singapore, BI Norwegian Business School and Stockholm School of Economics for helpful comments. Financial support from The Swedish Bank Research Foundation (BFI) is greatly acknowledged.
} 


\section{Introduction}

Whether or not access to consumer credit necessarily provides a benefit to households is inconclusive at best. The lack of consensus is most clear from the widespread existence of usury laws and regulating payday lending markets around the world. In theory, improved credit access can mitigate financial distress by allowing households to better smooth income or consumption shocks (Modigliani (1986)). However, if individuals suffer from financial illiteracy and forcasting problem (Stango and Zinman (2011); Bond et al. (2009)) or self-control problems (Laibson (1997); O'Donoghue and Rabin (2007)), access to finance may exacerbate distress due to their higher probability of making suboptimal borrowing and repayment decisions (Campbell (2006)). ${ }^{1}$ Indeed, surveys and experiments suggest that these problems are pervasive among households (Thaler (1981); Lusardi and Tufano (2009)).

I exploit the 2005 Bankruptcy Abuse Prevention and Consumer Protection Act (BAPCPA) to investigate how consumers respond to an increased access to credit and its subsequent impact on household distress. Before 2005, households with large unsecured debt burden could easily file for bankruptcy and get their unsecured debt discharged. The 2005 bankruptcy Act imposed significant barriers for households to file, which is most clear from the rush to file for bankruptcy just before the Act went into effect (Figure 1). First, high income borrowers are no longer allowed to file under Chapter 7 (the most favorable chapter), and instead have to file under Chapter 13 and repay more. Moreover, the Act raised the costs and delayed the time of filings substantially, which restricted access to bankruptcy for low income debtors. As most unsecured debt is discharged in bankruptcy, restricting access to bankruptcy increases unsecured creditors' right which should increase credit supply. Consistently, exploiting arguably exogenous cross-state variation in generosity of bankruptcy law prior to the Act, I find that households' access to credit and borrowing increased significantly more in states with higher exemption limits, where lenders were more exposed to losses from filings. Consequently, I show that this increased access exacerbated financial and economic distress among borrowers with low education and those with limited self-control due to their excessive borrowing and spending on unnecessary items.

In terms of type of debt, the direct effect of the reform should be on unsecured consumer debt such as credit card debt. In fact, a debtor remains roughly as vulnerable to secured creditors in bankruptcy as outside bankruptcy because secured lenders are allowed to foreclose on the property if the debtor defaults on its secured debt (Berkowitz and Hynes (1999)). Figure 2 plots the percentage changes in aggregate mortgage (secured) debt versus revolving (unsecured) debt in the US from 2002 to $2008 .^{2}$ While the growth of mortgage debt has been stable around the reform, revolving debt increased sharply after 2005. In 2006, revolving debt growth raised more than fourfold compared to 2004. This figure shows a dramatic change in the unsecured consumer credit market following the 2005 personal bankruptcy reform.

To identify the impact of the 2005 personal bankruptcy Act on households' access to credit and their financial wellbeing, an identification based on pre- vs post-reform differences could be misleading as it might capture the impact of other macro shocks that happened around the bankruptcy reform. As such, I rely on a cross-sectional identification strategy (difference-in-differences) that reveals the states where the reform should have had the biggest impact. I measure exposure to the reform by states' homestead exemption limits. These limits indicate the maximum amount of equity a debtor can exempt in bankruptcy. Therefore, if the 2005 Act caused an increased supply of unsecured credit,

\footnotetext{
${ }^{1}$ Models of self-control (time-inconsistent preferences) have been used to explain consumer borrowing, particularly borrowing at high interest rates. Under these preferences, individuals will sometimes choose to borrow even when doing so makes them worse off. They borrow under the assumption that they will repay the loan in one period, but they cannot commit to this plan. As a result, they end up borrowing and paying interest over many periods. There is a strong evidence that such self-control problems are embedded in the structure of the human brain (McClure et al. (2004)). For further discussions as well as more evidence for time-inconsistent behavior, see DellaVigna (2009).

${ }^{2}$ Revolving credit outstanding is often used as a proxy for credit card debt. Approximately 2 percent of consumer revolving credit is not on credit cards (CFA (2006)).
} 
the increase should be higher in states with higher exemption limits, where lenders were more likely not to be repaid in bankruptcy prior the Act. The exemption limits vary widely from state to state ranging from zero to unlimited (see Table 1), and are very persistent and depend mainly on exemption limits prevailing in the early 20th century due to strong inertia in the political process of reforming these limits (Hynes et al. (2004)). I also confirm this result in my analysis and show that states with different exemption limits are remarkably similar in characteristics such as income, homeownership, house price growth, education, race, and income inequality. ${ }^{1}$

I use data from the Panel Study of Income Dynamics (PSID) to investigate the impact of the 2005 bankruptcy reform on credit availability, household borrowings and the subsequent effect on households' distress. The PSID is a representative sample of US households which includes data on employment, income, different types of debt, wealth, expenditures, health, marriage, education, and numerous other topics. In addition, one of the advantages of PSID is that it is a longitudinal household survey, which makes it possible to follow households through time.

The estimated impact of the reform on household leverage is substantial after controlling for time and household fixed effects. A one-standard-deviation increase in the exemption limit was associated with a one-quarter-standarddeviation increase in household leverage as measured by unsecured debt-to-income. ${ }^{2}$ In addition, there is no evidence that secured debt-to-income was affected following the reform, confirming the prediction that the Act should only affect the unsecured credit market and reassuring that my identification strategy indeed picks up the impact of the bankruptcy Act.

I then study which households responded most aggressively to the availability of unsecured debt. Contrary to the predictions of the life-cycle model of consumption, I find no evidence that younger households, those with higher income growth or higher income volatility are borrowing more following the reform. ${ }^{3}$ Households with pre-reform high leverage (debt-to-income), low education, and those with self-control problem have the strongest tendency to borrow unsecured debt following the reform. ${ }^{4}$ These results suggest the presence of credit constraints at the household level under the assumption that high leverage is a proxy for borrowing difficulty to smooth consumption. However, the evidence that households with low education and those with self-control problems were borrowing aggressively is not explained by consumption smoothing behavior in that their income is unlikely to grow.

To better understand the underlying consumer financial behavior, I investigate how different borrowers used the debt. High leveraged borrowers used the borrowed money mainly to increase their medical care expenditures, suggesting that access to credit allowed these liquidity constrained households to increase their expenditures on expensive medical cares that they could not afford otherwise. Households with low education and those with self-control problems, however, used the debt mainly to increase their expenditures on apparel and recreational activities. This is surprising as one would not expect households with relatively constant income to borrow intensively from unsecured debt to fund their recreational activities.

In the next step, I address the impact of credit availability on households' distress. I am particularly interested in

\footnotetext{
${ }^{1}$ Note that the 2005 bankruptcy reform was a Federal law and did not change states' exemption limits.

${ }^{2}$ Note that this cannot be a demand effect; a demand story implies a larger decrease of demand in high exemption states. This result that increased supply of unsecured credit followed by increased unsecured debt is in line with Gross and Souleles (2002a), who studied how consumer debt responds to changes in credit supply using U.S. credit card data. Their findings suggest that an increase in credit limit generates significant and immediate rise in debt even for those who had not reached their credit limits.

${ }^{3}$ In line with this result, Mian and Sufi (2011) also find that households' borrowing from their home equity lines of credit and consuming it is inconsistent with the predictions of life-cycle model of consumption.

${ }^{4}$ Self-control problem is a self-reported measure of households' money management and self-control problem in spending, measured before the reform. Although this might be a noisy measure, people who self-report to have self-control problems tend to have larger unsecured debt and are more likely to smoke cigarettes which is consistent with the predictions of self-control models. See Section 5 for details.
} 
the effect on those households whose borrowing choices seem to be suboptimal from an ex ante perspective. The results suggest that the effect of increased access to credit and borrowing on households' financial health is not uniform across different types. Low educated households and those with self-control problems who were more exposed to the reform are significantly more likely not to be able to meet their mortgage repayments following the reform. In fact, I do not find any differential impact on households with high education in low vs high exemption limit states, suggesting that the cost of credit expansion was concentrated among low educated households. Specifically, going from a state with zero exemption limit to a median, the probability of facing a foreclosure for a low educated household increases by 0.9 percentage points (36\% increase of the average post reform foreclosure rates). For households with self-control problems the effect is even larger. A household with self-control problems in a median exemption limit state is on average 1.3 percentage points more likely to receive a foreclosure filing than a household living in a zero exemption limit state. High leveraged households in high exemption limit states, however, do not default relatively more, suggesting that high leveraged households were unambiguously better-off as a result of increased credit availability. These results are robust to controlling for variables measuring the severity of crisis such as changes in unemployment, housing price, and income.

As an alternative measure of household distress, I investigate the impact of the reform on households' food consumption. Food is the most necessary item among consumers expenditures and therefore a significant decline in food consumption has been used as a proxy for households' distress (Cochrane (1991); Karlan and Zinman (2010); Melzer (2011)). Using food consumption also implies that despite no impact on high leverage households, the bankruptcy reform brought about hardship among low educated households and those with self-control problems. Overall, the results are in line with the models of excessive borrowing due to financial literacy shortcoming (Stango and Zinman (2009)) as well as models of hyperbolic discounting and self-control problems (Laibson (1997); O'Donoghue and Rabin (2007)). ${ }^{1}$ Any alternative explanation must explain why we do not observe a differential effect for high leveraged borrowers in high vs low exposed states. While I cannot infer that improving credit access as a result of tougher personal bankruptcy law after 2005 was welfare-destroying for households with low education and those with self-control problems, the results do suggest that the debt service burden imposed by borrowing inhibits their ability to repay their loans, keep their home, and forces them to reduce expenditures on crucial items such as their food consumption.

A growing empirical literature addressing the impact of access to expensive credit has focused on payday lending market. Several studies find evidence suggesting that payday loan access has positive effects on households (Morgan and Strain (2007); Morse (2011); Zinman (2010)), whereas several other studies provide evidence suggesting that access to payday loans has negative effects on household financial condition and well-being (Melzer (2011); Skiba and Tobacman (2011); Carrell and Zinman (2008)). These papers use an instrument for access to credit but they do not have actual borrowings and therefore they are not able to investigate the impact on different types of borrowers. ${ }^{2}$ My paper looks at the access to credit in a much broader market (unsecured consumer credit) yet less expensive credit compared to payday loans. Thanks to my detailed household panel data, I am able to investigate the impact of increased access to credit for different groups of borrowers. The results support the models that highlight suboptimal borrowing choices due to financial illiteracy and cognitive biases (Lusardi and Tufano (2009); Stango and Zinman (2009)) as well as the models of self-control (Laibson (1997)). Overall, the results stress the adverse impact of unsecured credit availability for specific groups of borrowers and highlight the importance of addressing borrowers' heterogeneity in

\footnotetext{
${ }^{1}$ This result complements the results of Meier and Sprenger (2010) who use a field experiment and provide correlative evidence that people with time inconsistent preferences have more credit card debt.

${ }^{2}$ Zinman (2010) is the only exception; they conduct an experiment in South Africa and provide expensive credit to households. The drawback of their paper is that they mainly assess the short-run effect within 6 months after borrowing.
} 
this context. ${ }^{1}$

Previous papers have addressed the impacts of the 2005 bankruptcy reform. Using state-year data, Morgan et al. (2011) find that foreclosure rates among sub-prime (but not among prime) mortgages rose relatively more in high exemption states. They argue that as access to Chapter 7 bankruptcy became limited under the new law, less unsecured debt will be discharged in bankruptcy and hence borrowers are more likely to default on their mortgage loans. Using a similar identification strategy, Mookherjee and Lilienfeld-Toal (2011) argue that restricting access to Chapter 7 decreased the demand for housing and triggered the decline of house prices. However, as discussed in White (2008), most of the filers did not lose access to Chapter 7, as the sufficient condition to qualify for Chapter 7 is to have an income below the state median income and the median income of bankruptcy filers is half of the median household income. Moreover, based on the argument in Morgan et al. (2011), one would expect to see more foreclosures only among high income borrowers as they were the only group whose access to Chapter 7 was limited due to the reform. This, however, is in sharp contrast to what Morgan et al. (2011) find. Using a sample of mortgages from three months before to three months after the reform, Li et al. (2011) find that the reform increased mortgage defaults but do not find a larger impact on high exemption states in their sample. My paper complements these works by highlighting a new channel which relies on the dramatic rise of unsecured credit supply following the reform, due to increased costs of bankruptcy, and subsequent excessive borrowing by unsophisticated households. ${ }^{2}$ The paper not only provides an explanation for the puzzling result of Morgan et al. (2011) that only defaults among sub-prime borrowers increased but also reconciles it with the results of Li et al. (2011) who find no evidence in their sample (3 months around the reform) that defaults in high exemption states increased; if bankruptcy reform is to affect defaults through increased unsecured debt borrowing, one would not expect to see the effect within three month following the reform.

The results found in this paper have important implications regarding an appropriate bankruptcy law to reduce households' distress. Household bankruptcies in the U.S. increased steeply between 1980 and the mid-2000s, reaching an annual number of 1.6 million filings in 2004 representing $1.4 \%$ of all US households. Indeed, this surge was the main justification for the need of a tougher bankruptcy law (BAPCPA) as proponents of the reform argued that the current law is too soft so that many high-income borrowers are abusing the bankruptcy system. Empirical evidence, however, suggest that the Act restricted access to bankruptcy for poor people due to higher costs of filings and as a result the average income of filers increased following the reform (Lawless et al. (2008)). The results of my paper suggest that making it harder for consumers to file for bankruptcy would probably not result in lower indebtedness and lower financial distress. In contrast, when access to bankruptcy is limited, unsecured lenders increase the supply of credit and a large group of borrowers respond by taking on much more debt. Borrowers with low education and those with self-control problems are the victims of this increased supply due to their financial illiteracy, cognitive biases or time-inconsistent preferences. Hence, in order to reduce bankruptcy filings as well as households' financial distress, a proper policy should aim at reducing households excessive leverage and not at restricting access to bankruptcy for those who are already in distress.

\footnotetext{
${ }^{1}$ In line with these results, a 2006 survey of debtors who sought credit counseling prior to filing for bankruptcy found that the most important reason why households are in financial difficulty is because of "poor money management/excessive spending" (NFCC (2006)).

${ }^{2}$ It should be noted that some scholars and practitioners warned that the enactment of the BAPCPA encourages credit card product design that fosters unsustainable credit card lending at the expense of consumers (Mann (2006); White (2007); Bar-Gill (2004)). None of the papers, however, provide any empirical test.
} 


\section{U.S. Personal Bankruptcy Law}

\subsection{Bankruptcy Law Before 2005}

U.S. bankruptcy law has two main personal bankruptcy procedures: Chapter 7 and Chapter 13. Under both procedures, creditors must immediately terminate all efforts to collect their money once debtors file for bankruptcy. The main difference between the two Chapters is that Chapter 7 only requires bankrupts to repay from their assets, whereas Chapter 13 only requires them to repay from future income. Under Chapter 7 bankrupts list all of their assets. Some of assets are exempt by bankruptcy law, meaning that debtors are allowed to keep them. Asset exemptions are determined by the state in which the debtor resides. ${ }^{1}$ The most important asset exemption by far is homestead exemptions for equity in owner-occupied homes, which vary widely across states and ranges from zero to unlimited. Under Chapter 7, debtors must liquidate all of their nonexempt assets, which are used to repay creditors, but debtors are allowed to keep all of their post-bankruptcy income. Under Chapter 13, bankrupts are allowed to keep all of their assets, but they must use some of their post-bankruptcy income to repay. Before 2005, debtors were allowed to choose between the two procedures and the most commonly used procedure was Chapter 7 (around three quarters of all filings), as most debtors have few nonexempt assets and hence their gain was generally higher under Chapter 7 . Note that everything else equal, the higher the exemption limits, the less likely that unsecured creditors are repaid in bankruptcy.

\subsection{The Bankruptcy Abuse Prevention and Consumer Protection Act}

The number of personal bankruptcy filings increased dramatically (5-fold) in the US between 1980 and $2005 .^{2}$ As most of unsecured debt is discharged in bankruptcy, the rise of bankruptcy filing imposed extremely high cost on the lenders. For example, in 1997, bankruptcies led to a discharge of about $\$ 42$ billion of consumer debt, which is quite substantial when compared to, for example, state unemployment insurance (UI) programs that paid out a total of \$20.3 billion in the same year (Lefgren and McIntyre (2009)). These costs caused unsecured lenders to lobby long and hard so they finally succeeded in 2005 and The Bankruptcy Abuse Prevention and Consumer Protection Act was passed.

The Act made two important changes in bankruptcy law. The first was the adoption of a means test which does not allow higher-income bankruptcy filers to file under Chapter 7 and instead have to file under Chapter 13 where they are required to pay portion of their income for 5 years to creditors. ${ }^{3}$ The second major change under the 2005 bankruptcy reform was to raise debtors costs of filing for bankruptcy by imposing a number of new requirements on both debtors and bankruptcy lawyers. Debtors are now required to disclose additional information, submit copies of their tax returns, and receive credit counseling before they file. Bankruptcy lawyers are now subject to new registration requirements and they are liable if debtors provide false or misleading formation on their bankruptcy disclosure forms, which raised legal fees. The filing fees also increased. As a result, the average total filing costs under Chapter 7 rose from $\$ 900$ before the reform to $\$ 1,500$ after the reform and those under Chapter 13 rose from $\$ 3,700$ before the Act to $\$ 5,700$ after the Act (GAO (2006)). ${ }^{4}$ Overall, as also discussed in White (2008), the first of the two changes

\footnotetext{
${ }^{1}$ Note that bankruptcy law in the US is Federal law and therefore it is uniform for the whole country. However, the bankruptcy law allows individual states to set their own exemption limits.

${ }^{2}$ Authors have proposed different explanation for the rise of personal bankruptcy filings including increased credit card debt (Domowitz and Sartain (1999); Fay et al. (2002); Gross and Souleles (2002b)), bankruptcy filing becoming a middle-income phenomenon (Sullivan et al. (2000)), or the availability of casino gambling (Barron et al. (2002)).

${ }^{3}$ The sufficient condition to be able to file under Chapter 7 is to have an income below state median income. Those above median income might not be eligible depending on the results of earning exemption test. This test is, however, very generous so that as White (2008) argues: "The earning exemptions are high enough to allow most debtors to qualify for Chapter 7 even if their incomes are in top decile of income distribution".

${ }^{4}$ Gross et al. (2012) find that legal and administrative costs inhibit a significant number of households from filing for bankruptcy. Their lower
} 
was intended to discourage higher-income debtors from filing by forcing them to repay some of their debt in Chapter 13, while the second of the two changes was intended to discourage lower-income debtors from filing by raising their costs. In addition to these two important changes, BAPCPA also increased the minimum time that must elapse between bankruptcy filings: from six to eight years for Chapter 7 filings and from six months to two years for Chapter 13 filings; and from no minimum to four years for a Chapter 7 filing followed by a Chapter 13. These changes implies that at any given time, fewer debtors are eligible for bankruptcy. State-specific asset exemption levels remain in effect.

Overall, the adoption of the Bankruptcy Abuse Prevention and Consumer Protection Act raised costs of filing for bankruptcy, lowered the amount of debt discharged in bankruptcy, increased the amount of future income that debtors must use to repay, and increased the minimum time needs to be passes to be able to file again. All of these changes made U.S. bankruptcy law more pro-creditor. Delaying the time and raising the costs of filing for bankruptcy, the reform allows unsecured lenders to collect more on their loans through different methods such as wage garnishments, collection calls, late payment fees, etc. (Mann (2006)). Moreover, the fact that some of filers have to file under Chapter 13 also means that unsecured creditors will be repaid more. Not surprisingly, personal bankruptcy filings surged to two million in 2005 as debtors rushed to file under the old law and then fell sharply to 600,000 in 2006.

\section{Theoretical Arguments}

As discussed above, in terms of the type of debt, changes in personal bankruptcy law primarily affects the market for unsecured credit. Now the question is that how does a bankruptcy reform which is pro-creditor affect equilibrium household borrowing of unsecured credit? The prediction regarding the supply side is unambiguous in that lenders' ability in collecting their loans increases and therefore credit supply should increase. However, the theoretical answer on the demand side depends on the underlying model of consumer behavior.

An unconstrained consumer would reduce her demand since the cost of bankruptcy and the expected loss from filing bankruptcy has increased. However, another possibility is credit-constrained consumers who want to borrow more today to smooth consumption over time but are unable to do so due to credit rationing. Such consumers would borrow more following the reform to relax their budget constraints. Alternatively, consumers with limited self-control may aggressively borrow in order to finance current consumption even though when doing so makes them worse off (Laibson (1997); O'Donoghue and Rabin (2007); Heidhues and Koszegi (2010)). They borrow under the assumption that they will repay the loan in one period, but they cannot commit to this plan. As a result, they end up borrowing and paying interest over many periods. Therefore, individuals who are likely to fall in temptation may prefer the discipline of lacking access to credit before temptation arises (Gul and Pesendorfer (2001); Gul and Pesendorfer (2004); O’Donoghue and Rabin (2007); Fudenberg and Levine (2006)). Finally, borrowers might be misinformed about their ability to repay loans in the future (Bond et al. (2009)) or underestimate the interest rate on short term loans (Stango and Zinman (2009)) and hence borrow heavily following credit availability. I will try to distinguish between these theories by testing their implications. For example, younger households, those with higher income growth or higher income volatility are more likely to borrow to smooth their consumption. Moreover, education could be used as a proxy for financial literacy and household sophistication.

Similarly, it is not unambiguous how increased credit availability affects households financial hardship. On the one hand, improving access to credit, even if very expensive, allows credit constrained households to not only smooth

bound prediction suggest that more than 60,000 households will have difficulty saving up for filing costs in 2012 . 
their consumption but also meet payments of their important bills and repay their loans when they receive a shock to their income. On the other hand, credit availability might induce some households to over-borrow and over-consume so that the future costs of borrowing outweight the initial benefits for these households, even from an ex ante point of view. The sources of over-borrowing could be limited self-control (Laibson (1997); Laibson et al. (Forthcoming); O’Donoghue and Rabin (1999)) or lack of financial literacy and cognitive biases (Johnson et al. (2001); Lusardi and Tufano (2009); Stango and Zinman (2009); Bertrand and Morse (2011)).

\section{Identification}

Empirical strategy of this paper is designed to estimate the effect of 2005 personal bankruptcy reform on household leverage as measured by unsecured debt-to-income ratio and its subsequent impact on household financial health. As the aggregate data in Figure 2 shows, unsecured debt grows significantly after the reform. However, an identification based on pre- vs post-reform could be misleading as I might capture the impact of other macro shocks that happened around the bankruptcy reform. Note that BAPCPA took effect at the same time in every state and other policies might have changed at the same time. As such, I rely on a cross-sectional identification strategy that reveals the states/households where the reform should have had the biggest impact. My identification strategy mainly follows that of Morgan et al. (2011) and Mookherjee and Lilienfeld-Toal (2011).

I measure exposure to the reform in two different but related ways. First, I take states' homestead exemption limits in 2005 where a higher exemption means a higher exposure of the state. The logic behind this is straightforward: unsecured lenders were more exposed to losses from debtors' filing for bankruptcy in high exemption states. Therefore, making bankruptcy more difficult and costly should increase credit supply more in higher exemption limit states.

There is one complication in using homestead exemption limits as a measure of exposure to the reform as some states have unlimited exemption limits. To deal with this, I add a dummy for states with unlimited homestead exemption and for other states I measure homestead exemptions as a continuous variable. The resulting specification is:

$$
y_{i s t}=\beta_{0}+\beta_{1} \times \text { Post }_{t} \times \text { Exposure }_{s}+\beta_{2} \times \text { Post }_{t} \times \text { Unlimited }_{s}+\gamma X_{i}+\delta Z_{t}+\varepsilon_{\text {ist }}
$$

$y_{i s t}$ is leverage of household $i$ in state $s$ in year $t$. Post is a dummy for post-reform period, exposure is the size of homestead exemption limit, Unlimited is a dummy variable for states with unlimited exemption level. $X_{i}$ is household fixed effects that control for time-invariant observed/unobserved differences across households and $Z_{t}$ is time fixed effects that control for all macro shocks that affect all states. Therefore, the coefficient of interest, $\beta_{1}$, estimate the differential impact of the reform on those states with higher exposure to the new bankruptcy law.

In the second option, I measure the exposure to the reform by states' homestead exemption relative to the median states' house price.

$$
\operatorname{LogExMinS}=\log (\min \{\text { Median States’ House Price, Homestead Exemption Limits }\})
$$

The logic behind using the second exposure is as follows. Consider household 1 and household 2 with home value 
of $\$ 100$ and $\$ 150$ thousand respectively. Assume that the former lives in a state with homestead exemption limit of $\$ 50$ thousand, whereas the latter lives in a state with $\$ 300$ thousand exemption. In the case of bankruptcy, the maximum exemption for the former is $\$ 50$ thousands (cannot get more because this is the limit), whereas for the latter is only $\$ 150$ thousand (maximum home value). Using the second exposure measure leads to the following specification:

$$
y_{i s t}=\beta_{0}+\beta_{1} \times \text { Post }_{t} \times \text { Exposure }_{s}+\gamma X_{i}+\delta Z_{t}+\varepsilon_{i s t}
$$

where the main difference is that exposure is now LogExMinS. Not only using a relative measure of exposure is probably a more precise proxy, using this specification does not require a separate dummy for states with unlimited exemptions. Although I verify the main results using both measures, for most of the analyses, LogExMinS is used.

\subsection{Determinants of Exemption Limits}

As discussed above, exemption limits are determined at the state-level and therefore exemption levels might reflect economic or political characteristics of individual states. Previous literature has tried to explain the cross state variation in exemption limits (see, for example, Hynes et al. (2004) and Mookherjee and Lilienfeld-Toal (2011)). They test a number of different theories and use a large set of variables, yet they find that the main robust determinant of exemption limits are exemption limits prevailing in early 20th century. Indeed, many of the current laws still contain extremely archaic provisions. In Oklahoma, for example, a debtor can exempt a gun, twenty head of sheep, and all provisions and forage on hand. Moreover, as discussed in Fan and White (2003), there has been only few changes in exemption limits each year since 1980s, mainly due to adjustments for inflation, which allows researchers to treat exemption limits as exogenous (Gropp et al. (1997); Fay et al. (2002)). In fact, correlation coefficient between the level of homestead exemption limits in 1995 and 2005 is $0.98 .^{1}$

Despite this evidence, I try to investigate whether my data shows any correlation between exemption limits and states' characteristics. Table 4 presents cross-state regressions for the log of the 2005 exemption limits on various state-characteristics such as household income, house price growth, homeownership, house value, total debt-to-income ratio, income inequality, family size, unemployment rate, education, business ownership among others. In the first and second columns, states with unlimited exemption are taken to have exemptions of 1 million dollars. The first column shows that the best predictor of states' exemption limits are historic (1975) values of exemption limits. Among all other characteristics, only unemployment rate and family size are significant. Column 2 drops historic exemption levels, and again only unemployment rate appears significant in the regression. Note that house price growth has not been higher for states with higher exemption limits, suggesting that housing bubble at the state level was not correlated with exemption levels. As I have only 51 observation (the number of states) in the regression, I run a series of unreported regressions with a subgroup of explanatory variables in Table 4 in order to increase statistical precision of the estimates. The results are in line with the previous results.

Column 3 and 4 conduct the same exercise for my second exposure measure which was the log of minimum of exposure limits and median states' house value. Not surprisingly, the same conclusion comes out of these two regressions: the most significant and robust determinant of 2005 states exemption limits is historic values of exemptions limits. In these two regressions none of other states' characteristics seem to be significantly correlated with the level of states' exemption limits. In sum, my analysis of determinants of exemption limits is consistent with the literature

\footnotetext{
${ }^{1}$ In this calculation unlimited exemption is taken to get the value of 1,000,000 dollars.
} 
that whatever factors determine states exemption levels, they appear to be very persistent. Only unemployment rate and family size turn significant in some regressions. Therefore, I will control for these two variables in the analysis.

\section{Data and Descriptive Statistics}

\subsection{Data}

\subsubsection{Household Balance Sheet and Characteristics}

The identification strategy of this paper requires at least a dataset representative of US households with information on households balance sheets and their state of residence. The Panel Study of Income Dynamics (PSID) is the best choice, as it not only has all the above properties but also is a longitudinal dataset and allows me to follow households through time.

PSID is a longitudinal household survey started in 1968 with a nationally representative sample of over 18,000 individuals living in 5,000 families in the US. Information on these individuals and their descendants has been collected ever since and it includes data on employment, income, debt, wealth, expenditures, health, marriage, education, and numerous other topics. The survey was administered by the University of Michigans Survey Research Center every year from 1968 through 1997 and every other year since then. The most recently released full wave contains information from about 8,000 interviews conducted in 2009. The supplemental wealth module was introduced in 1984 and was conducted on a periodic basis prior to 1999 (the 1984, 1989, and 1994 waves). Since 1999, however, the wealth and active saving questions have been included in each wave (1999, 2001, 2003, and 2005, 2007, 2009).

The PSID contains fairly extensive information about mortgages on primary residences as well as loans used to finance motor vehicle purchases. I calculate the mortgage debt of each household as the sum of the balances of any first and second mortgages on its primary residence. Then I calculate vehicle debt of each household using the information is given about the number of payments and the initial loan for each vehicle. I refer to the sum of mortgage and vehicle debt as secured debt. In addition, PSID reports balances on other common types of household debt such as credit cards and student loans. I refer to these types of debts as unsecured debt, the type of debt this paper is mostly about. PSID does not report separate statistics for different types of unsecured debt, yet for the purpose of this study I am mainly interested in the changes in unsecured debt, not the components of it. The PSID also provides detailed information about different types of household assets and their wealth. For income, I use total family income before taxes, as information about after-tax income is not available. Interest rate is the interest homeowners pay on their primary mortgage. To make magnitudes comparable over time, I convert all values to 2005 dollars using the consumer price index.

In the 2009 survey of PSID, households were asked to provide information about foreclosure activities related to their home. Specifically, households were asked whether foreclosure started in any of their homes during the past 8 years, i.e., since 2001, and if yes, which year and month it started. Therefore, I have data about foreclosure-starts for each household in every year since 2001 although other variables are given biannually because the survey is conducted biannually. I convert foreclosure data to match other variables. For example, foreclosure variable for a household gets one in year 2008 if the household has received a foreclosure filing in year 2007 or 2008 and zero otherwise. Food consumption is the sum of expenditures on food at home, food eaten out, and the value of food stamps for each 
household.

In the 2005 survey, households were asked: Do you have difficulty managing your own money, such as keeping track of expenses or paying bills? Those who answered "Yes" are considered as those with self-control problems. The literature on self-control problem and time inconsistent behavior predicts that individuals with self-control problems tend to have lower savings, higher credit card debt and are more likely to smoke (Laibson (1997); Gruber and Kszegi (2001); Harris and Laibson (2002); Laibson et al. (2003); DellaVigna and Paserman (2005)). Although imperfect, the self-reported self-control problem seems to do a good job capturing these patterns. As Table 5 shows, those with self-control problem in PSID data tend to have higher unsecured debt and are more likely to smoke yet they are not different from others in age, education and homeownership.

To test the implications of lifecycle hypothesis, I need the growth and volatility of household income. I use income growth and volatility in each industry from Eiling (Forthcoming) who calculates quarterly returns and its standard deviation of industry-specific human capital in nine different industries and are as follows (the first number is the return and the second is volatility): mining $(1.44 \% ; 2.50 \%)$, construction $(1.16 \% ; 1.03 \%)$, manufacturing $(1.21 \%$; $1.10 \%)$, transportation, communication, and utilities $(1.16 \% ; 1.18 \%)$, wholesale trade $(1.24 \% ; 1.23 \%)$, retail trade $(1.02 \% ; 0.69 \%)$, finance, insurance, and real estate $(1.44 \% ; 2.80 \%)$, services $(1.39 \% ; 0.94 \%)$, and government $(1.13 \%$; $0.78 \%)$. For each household, income growth and volatility is taken to be the income growth and volatility of the industry in which the head is engaged in.

The sample is restricted to households that had a complete set of interviews for the 2003, 2005, 2007, and 2009 waves of the PSID. Unless otherwise stated, I use the variable year as the working year, not the survey year as, for example, the 2003 survey, conducted in beginning of 2003, records information about year 2002. Therefore, I use data for working years $2002,2004,2006$, and 2008. When investigating the impact of the reform on household leverage, I use data from 2002 to 2006 . The data for year 2008 will be used later to evaluate the impact of household borrowing due to the 2005 bankruptcy reform on household distress in the years following the reform. Finally, the calculations presented throughout the paper are based on weighting the PSID observations, which makes the data representative of the population.

Data on 2005 states' homestead exemptions are taken from Morgan et al. (2011). Table 1 presents homestead exemption limits across states. As shown, there is a wide variation between exemptions ranging from 0 (e.g.: in New Jersey and Maryland) to unlimited homestead exemption limits (e.g.: Arkansas, Iowa, and Texas). The median exemption limit is $\$ 40$ thousands and the mean is about $\$ 60$ thousand (excluding unlimited states from calculation of the mean).

\subsection{Summary Statistics}

Table 2 presents summary statistics for the full sample and Table 3 breaks down summary statistics (for the main variables used in the paper) to pre and post reform. The median household income in 2006 is $\$ 48,200$. As expected secured debt is the largest part of overall household debt (more than \% 80), but its share fell by about 0.6 percentage point in 2006. The mean total household debt outstanding as of 2006 is $\$ 67,800$ in the PSID data. The percent of households holding a mortgage is $50 \%$ and for those who have mortgage, the median value is $\$ 102,000$. The average interest on mortgages is $6.5 \%$. Having unsecured debt is more common than home debt. 55\% of households in PSID have some kind of unsecured debt and the median is $\$ 8,900$. The average total debt of households is $\$ 110,200$ and the 
median is $\$ 67,800 .^{1}$

Household total leverage as measured by total debt-to-income ratio is on average 1.23 for all households. This value before the reform was 1.26 while after reform reached to 1.37. Household leverage due to unsecured debt, measured by unsecured debt-to-income ratio increased with a much higher pace from 0.23 to 0.37 . While the proportion of households with a mortgage increased only one percent after the reform, the proportion of households who holds unsecured debt increased by 4 percentage points to $57 \%$.

Based on the PSID data, 1.79 percent of households with a mortgage received at least one foreclosure filing during 2008, up from 0.91 percent in 2007. These numbers are in line with the corresponding statistics for the whole US households, which was 1.03 percent and 1.84 percent per household in 2007 and 2008. ${ }^{2}$ Aggregating 2007 and 2008 foreclosures data, 2.70 percent of households received a foreclosure filing based on the PSID data, while this number is about 2.85 percent for the whole US. Therefore, the PSID data closely mirrors the actual foreclosure data. The average foreclosure rate in the sample is $1.45 \%$.

\section{Bankruptcy Reform and Household Leverage: Graphical Motivation}

Figure 3 plots the average growth of secured versus unsecured debt before and after the reform using the PSID data. As shown, while the growth of secured debt was barely affected between 2004-2006, the growth of unsecured debt increased more than twofold in 2006. This result is also true when one looks at debt to income. This clearly suggest that whatever caused the increase in households' unsecured debt was not a global factor that impacted all types of debt. Rather, it was a specific shock to unsecured credit market.

Although Figure 3 shows a large increase of households' unsecured debt and their leverage between 2004-2006, they have little to say whether bankruptcy reform contributed to this trend or not. The changes in unsecured debt might well be due to another change in the unsecured credit market or any other secular changes. Therefore, we need a control group within the group of unsecured borrowers to compare the changes in unsecured debt before and after for the treatment and the control group. In fact, it is the basis of my identification strategy that high exemption states should be affected harder if the effect comes from the bankruptcy reform. As explained before, the reason is that households in high exemption states are expected to be more credit constrained.

Figure 4 plots the average unsecured debt-to-income ratio for states with high and low exemption limits before and after the reform. The time of the reform is shown as the vertical red line. I use states in the lowest and the highest quartile of exemption limits (below $\$ 10,000$ and above $\$ 150,000$ ) to form the two classes. Figure 4 highlights two important points. First, household unsecured leverage for low and high exemption states had a parallel trend before the reform. Second, both high and low exemption states experienced a change in their households' leverage, but the effect was much larger for high exemption states. The figure clearly suggest that household borrowing of unsecured debt increased substantially following the reform and as expected the increase was much more for households in high exemption states. This figure supports the idea that as unsecured lenders were more likely not to get back their money in high exemption states before the reform, the supply of credit was more limited in those states. Following the reform, lenders of unsecured credit responded by increasing volume of credit and households increased their borrowings.

\footnotetext{
${ }^{1}$ Note that the average and median for each variable is calculated based on households who hold a positive amount of that variables. In addition, the values are similar to the corresponding values in the 2007 Suvey of Consumer Finances (see Bucks et al. (2009)).

${ }^{2}$ This data is from Realtytrac.com, the leading online marketplace for foreclosure properties.
} 


\section{Regression Analysis}

In this section, I proceed with regression analyses to estimate the precise effect of the 2005 bankruptcy law on household leverage as well as identifying which households are taking on more debt following the reform. Next I examine the real short term and long term impacts of higher access to credit for different types of borrowers.

\subsection{Bankruptcy Reform and Household Leverage}

The impact of the 2005 bankruptcy reform on household leverage is presented in Table 6, using household fixed effects and time dummies as well as different exposure measures. The impact of the reform on household unsecured debt is shown in columns 1-3, while the effect on household secured debt is reported in columns 4-6. The columns differ by the exposure measure used as well as control variables. Within each set, the first three columns differ in the exposure measures used, while the fourth column of each set adds a set of household time-varying control variables that could potentially affect household leverage.

Column 1 and 2 of Table 6 show that higher exposure to the reform leads to a larger increase in household leverage after the reform due to increased unsecured debt. The magnitude of this effect is substantial. The estimate of 0.102 in column 1 implies that a one-standard-deviation increase in exemption limits was associated with a onequarter-standard-deviation increase in unsecured debt-to-income ratio. To put it differently, going from a state from zero exemption to the median, the unsecured debt-to-income increases by 0.2 , which implies a $50 \%$ increase of the average households' unsecured debt-to-income ratio. The coefficient for the unlimited exemption limit states is also positive (0.084) and significant at $10 \%$ level; households living in unlimited exemption states took on relatively more unsecured debt compared to average of other states following the reform.

In column 3, I control for some other variables that might vary at the household level and are probably related to household debt such as homeownership, family size, education, and weeks unemployed. Only family size and education appear to be significant. As expected, households with larger sizes and those with higher education have more unsecured debt. Despite this, the statistical as well as the economic significance of the reform on household unsecured debt stays unchanged. In sum, the leverage of households who were more exposed to the generosity of the bankruptcy law before 2005 increased more following the reform. This shows that as access to bankruptcy became more restricted, lenders of unsecured debt increased the supply of credit substantially, and the increase was much more in states where pre-reform bankruptcy law was more pro-debtor. Note that the increased leverage is obviously a supply effect in that the demand effect would suggest a larger decrease of household leverage in high exemption states, exactly an opposite effect to what I find.

Columns 4-6 of Table 6 show no increase of household secured-debt-to-income ratio following the reform. In one of the specifications, the estimated coefficients is positive and in two others are negative and they are all statistically insignificant. The fact that the increased borrowing and leverage is concentrated in households' unsecured debt is consistent with the prediction that the reform should affect borrowing and lending of unsecured debt. In addition, the fact that the change in household secured debt was not different between households with different exposures shows that the results are unlikely to be driven by other factors than the bankruptcy reform. Any alternative explanation for the larger increase in unsecured debt-to-income ratio for household with a higher exposure must explain why the effect is absent for households' leverage as measured by secured debt-to-income ratio. 
An alternative specification using the log of debt levels as dependent variable also shows a positive and significant effect of the bankruptcy reform on household leverage. Table 7 presents the results. The results are consistent with the main specification using households' debt-to-income ratio. The reform has a positive effect on household unsecured debt-taking, but no impact on secured debt levels. The coefficient in column 1, row 1 implies that the increase in unsecured debt in a state with median exemption limit was $40 \%$ larger than a zero exemption limit state, which is quite significant and in line with the results of the main regressions using household leverage as the dependent variable.

Overall, these results strongly suggest that following the reform, unsecured lenders increased the supply of credit and as a result households took on large amount of unsecured debt so that their leverage as measured by unsecured debt to income increased substantially. This is consistent with the recent research on the determinants of the level of credit card debt and of the extent of utilization of credit lines that has found that credit line increases initiated by banks themselves do contribute to increases in the amount of debt revolved, suggesting that credit card debt revolvers appear to have target utilization rates of their credit lines (Bertaut and Haliassos (2006)). In order to confirm this argument as well as addressing how households spent the borrowed money, in the next section I investigate the impact of the reform on household expenditures.

\subsection{Does Borrowing Vary by Consumer Type?}

Exploring the cross-sectional heterogeneity of the effect provides important insights into the underlying model of consumer behavior that is most consistent with the increased borrowing following the bankruptcy reform.

Table 8 presents estimates of the following specification:

$$
\begin{aligned}
y_{i s t} & =\beta_{0}+\beta_{1} \times \text { Post }_{t} \times \text { Exposure }_{s} \times \text { InteractionTerm }_{i}+\beta_{2} \times \text { Post }_{t} \times \text { Exposure }_{s} \\
& +\beta_{3} \times \text { Post }_{t} \times \text { InteractionTerm }_{i}+\gamma X_{i}+\delta Z_{t}+\varepsilon_{i s t}
\end{aligned}
$$

where $y_{i s t}$ is unsecured debt-to-income of household $i$ in state $s$ at time $t$. Interaction term, in different regressions, is age of household's head, leverage (total debt to income), income growth and income volatility based on the industry of head (taken from Eiling (Forthcoming)), and households' self-reported self-control problem, all measured before the reform (in 2004) except income growth and income volatility that are calculated from historical data. $\beta_{1}$ is the coefficient of interest. Note that the level effects of Post, Exposure, and interaction term are absorbed by household and time fixed effects. Similarly, the coefficient on (Exposure x InteractionTerm) is not identified as it is constant for each household over time.

In column 1 to 3 test the implications of lifecycle hypothesis, where I investigate whether younger households, those with higher income growth or income volatility are borrowing more to smooth their consumption or not. Contrary to the predictions of life-cycle models of consumer borrowing, there is no evidence that these households are borrowing relatively more following the reform. Similar result is found by Mian and Sufi (2011) in the context of borrowing from home equity lines of credit. Debt-to-income could also be a measure of household's credit constraints. The estimated coefficient on the interaction term for high leverage households is negative (column 4), which implies that the impact of the bankruptcy reform on household leverage is higher for high leverage households; unsecured debt-to-income ratio of households with high leverage increased more in more exposed states. The magnitude of the difference is 
relatively large. For a household in a median exemption limit state and one standard deviation below the mean 2004 household leverage, unsecured debt-to-income increases by 0.09 . For a household in the same state but one standard deviation above the mean 2004 household leverage, the change is 0.17 . To the extent that high leverage proxies for being credit constrained, this result show that households in higher exemption limit states were relatively more credit constrained before the reform.

The last two columns of Table 8 investigate the implications of behavioral models that predicts households with low education or those with self-control problems borrow more. The negative estimate on the interaction term in column 5 implies that households whose head is less educated also borrow substantially more in more exposed states. The estimated effect is quite substantial. For a household in a median exemption state and one standard deviation below average education, the increased leverage is 0.21 , while this increase for a household one standard deviation above average is only 0.06. As the income of households with low education is not expected to rise, it is hard to rationalize this large unsecured credit borrowing by low educated households following the credit availability. This behavior, however, is in line with the models that suggest households underestimate the cost of increased leverage or the magnitude of interests they have to pay and therefore responding more aggressively to credit availability (Stango and Zinman (2009)).

The last column investigates the differential impact of the reform on borrowing of those households who selfreport that they have money management problems and cannot keep track of their expenses and paying their bills, which could be a measure of self-control problem as explained before. The estimated coefficient implies a substantial increase of leverage for households with self-control problems. In particular, households with self-control problem in a median exemption state increased their leverage, on average, by 0.11 compared to households in a state with zero exemption levels. This increased leverage is above and beyond the average increased leverage for households in the median exemption state. Therefore, the impact of the reform was particularly substantial for households with self-control problem.

Overall, the evidence strongly suggest that following the reform, the pool of borrowers became riskier. Households with high leverage, low education and those with self-control problem were those who took on more unsecured debt, and as a result their leverage as measured by unsecured debt-to-income increased sharply. As the bankruptcy law made bankruptcy more difficult and increased the barriers to file for bankruptcy, unsecured-debt lenders had the incentive to lend more to riskier borrowers. While there is evidence that some credit constrained (high leverage) households were borrowing to smooth their consumption, aggressive borrowing of low educated households and those with self-control problems cannot be explained by consumption smoothing in that their income is unlikely to grow. In the next section, I address how different types of consumers use the debt.

\subsection{How Are Consumers Using Debt?}

What do consumers do with the money borrowed following the 2005 bankruptcy reform? This question is important in order to better understand the model underlying consumer choices. To address this issue, I investigate the impact of the reform on different categories of household's consumption expenditures. Specifically, I divide expenditures to 6 categories: utility, furnishing, schooling, transportation, apparel and recreation, and medical care. I run regressions similar to Equation 3 where the dependent variable in different regressions is the log of household expenditures in each category. As in case of leverage, I investigate which types of households are spending more and on what they spend the debt. This is a more direct way of testing different models underlying consumers's financial behavior. Table 
9 presents the results. Note that each number in the table corresponds to a $\beta_{1}$ in a regression similar to Equation 3 . The difference is either the dependent variable (column title) or the interaction term used.

The first three rows examine age, income growth, and income volatility as an interaction term to test whether younger households, those with higher income growth and those with higher income volatility in high exposed states are spending more following the reform or not. As shown, none of the coefficients are estimated statistically different from zero, implying that households with the above characteristics are not spending more than the others. This confirms the earlier results on leverage, where I found that younger households, those with higher income growth or higher income volatility were not borrowing more following the reform. Therefore, again the results does not support the predictions of life cycle models of consumption where households borrow to smooth their consumption.

Rows 3 to 6 examine the differential effect on households with high leverage, low education, and those with self-control problems. As shown, we do observe an increase of expenditures for these households. Note that these households are those who also borrowed more unsecured debt following the reform. The increased expenditures, however, is not uniform across different categories for different household types. Households with high leverage use the debt quite differently from households with low education and those with selfcontrol problems: while high leveraged households mainly increase their medical care expenditures, the other two groups mainly spend the debt on apparel and recreational activities. These effects are economically quite large. For instance, low educated houshoelds in a median exposure state increased their expenditures on clothing and recreational activities by $8 \%$ more than those in a zero exposure state. The corresponding number for households with self-control problem is $11 \%$. These estimated effects are not what one would expect from a rational model of consumption in that households whose income are not likely to increase borrow aggressively on a relatively expensive credit to fund their recreational activities. The reason why households with high leverage in high exemption states increase their medical care expenditures following the reform could be that these households were liquidity constrained before the reform but now have access to credit and undertake necessary yet expensive medical cares such as MRI and the like, or they are insuring themselves against future negative health shocks. There is another category of consumption that was increased somewhat similarly across all three category of borrowers: spending on repairment and furnishing home. Households with high leverage, low education and those with self-control problems in a median exposure state are increasing their consumption of this category by about 3 to $5 \%$ more than those in a zero exposure state. There is no evidence, however, that expenditures on utilities, schooling, or transportation changed following the reform.

Overall, the results suggest that access to credit following the reform allowed high leverage households to invest on their healthcare, whereas low educated households and those with self-control problems used debt mainly for apparel and recreational activities. It comes out of surprise that some households who are not expected to see a rise in their income use relatively expensive credit to spend on clothing, vacation and recreational activities. In the following section, I investigate whether households whose access to credit increased following the reform face a higher or a lower level of financial difficulty.

\subsection{Bankruptcy Reform, Increased Leverage, and Household Distress}

How did improved access to credit following the bankruptcy reform affect the financial well-being of households? I have shown that increased credit access allowed some groups of borrowers (high leveraged, low educated and those with no self-control) to borrow more and increase their consumption. Now I investigate whether increased access for these groups made them more or less vulnerable in the years following the reform. As explained before, whether 
improving access to credit alleviates or exacerbates financial hardship is not theoretically unambiguous. While improved access could allow households to be able to make their important payments when they receive a temporary shock, higher availability of credit itself might increase households financial distress if it causes over-borrowing and over-consuming.

Figure 5a examines total foreclosure-start rates for homeowners with a mortgage in the highest and lowest quartile states' exemption limits. After 2005 (time of the reform) foreclosure rates in high exemption states start to increase so that the difference becomes relatively large by the end of 2008. This suggest an increased distress among households living in high exemption states. Note that the increase starts well before the start of financial crisis in late 2007 , suggesting that increased default is unlikely to be a result of the crisis. Now I plot the same graph for different types of households whose access to credit increased following the reform to see whether improving access to credit made them more or less likely to default. Figures 5b and 5c examine the lowest and highest quartile of 2004 households leverage, respectively. The figures show that high and low leverage households are not different in their default rates in high vs low exemption limit states. This suggest that the increased default rates in high vs low exemption states is not coming from (2004) high leverage households.

Figures 5d and 5e examine the lowest and highest quartile of households based on their heads' education. It is very clear that low educated households in high exemption states are defaulting relatively more. Remember that following the reform and higher credit availability in high exemption states, low educated households were those who increased their borrowing substantially. In fact, Figure $5 \mathrm{~d}$ shows no difference between default rates of high education households in high vs low exemption states. More interestingly, Figures $5 \mathrm{f}$ and $5 \mathrm{~g}$ investigate the default rates of those who self-reported (before the reform) they have money management problem and they believe they are not able to keep track of their expenditures properly. While those who self-reported they have self-control in high exemption limit states are defaulting relatively more, this differential impact for those with no self-control is quite substantial. Note that the trend seems to be similar before the reform, and it is only after the reform that the default rates of households in high vs low exemption states start to diverge. Overall, the figures suggest that while high leverage households were better off as a result of the reform, low educated households and those with self-control problems were the types of households whose increased access to credit did not make them unambiguously better-off.

Table 12 shows estimates of the following specification for different groups of borrowers (denoted by InteractionTerm) using a linear probability model: ${ }^{1}$

$$
\begin{aligned}
y_{\text {ist }} & =\beta_{0}+\beta_{1} \times \text { Post }_{t} \times \text { Exposure }_{s} \times \text { InteractionTerm }_{i}+\beta_{2} \times \text { Post }_{t} \times \text { Exposure }_{s} \\
& +\beta_{3} \times \text { Post }_{t} \times \text { InteractionTerm }_{i}+\beta_{4} \times X_{i s t}+\gamma D_{i}+\delta Z_{t}+\varepsilon_{i s t}
\end{aligned}
$$

where $y$ is a binary variable and is 1 if household $i$ in state $s$ at time $t$ defaults on its mortgage and zero otherwise. InteractionTerm is referred to different groups of households who borrowed more following the reform. Specifically, in different regressions, the interaction term is leverage, education, and a dummy for those with no self-control. $X_{i s t}$ is a set of three variables that might be correlated with the probability of a household facing foreclosure: home price appreciation, the number of weeks unemployed, and logged income. The coefficient of interest is $\beta_{1}$ which estimates a triple difference: before and after the reform, high vs low exemption limit states, and high vs low level of

\footnotetext{
${ }^{1}$ The reason why I use a linear probability model is that as discussed by Ai and Norton (2003) interaction terms in non-linear models does not provide difference-in-differences estimator.
} 
interaction term (e.g.: high vs low leverage). Note that the level effects of Exposure and Exposure $x$ InteractionTerm is captured by households effects therefore the estimate of $\beta_{1}$ is not driven by states with different exposures being affected differently during the crisis. Similarly, the result is not driven by some specific groups of households (e.g: high leverage) defaulting more following the reform.

Panel A of Table 12 reports regression results with no control variable. The estimated coefficients on Post $x$ Exposure are positive and significant, which means that households in states with higher exposure to the reform are facing more difficulty paying their mortgages and defaulting more following the reform. This is in line with Mookherjee and Lilienfeld-Toal (2011) who find that home prices in high exemption states were hit harder as a result of the reform. More importantly, homeowners in more exposed states and with high leverage in 2004 (those who also borrowed more following the reform) are not more likely to be in financial difficulty (columns 1). However, low educated households and those with self-control problems in high exemption states (the other two groups who aggressively borrowed following the reform) are facing a much greater probability of being in distress following the bankruptcy reform (column 2 and 3). More specifically, going from a state with zero to median exposure, the probability of default for a household whose head has high school diploma is only increased by 0.2 percentage point, whereas this increase for a household whose head has no high school diploma is 1.1 percentage points. These estimates imply that about $85 \%$ of the higher increase in default in high exemption states following the reform is accounted by low educated households. In addition, the results of column 4 show that households with self-control problem in consuming and spending are also facing a much larger likelihood of default in high exemption states following the reform. The coefficient of 0.006 on the self-control problem interaction implies that going from a zero exemption state to a median, the probability of default for a household with self-control problems increases by 1.3 percentage points.

Panel B of Table 12 presents the results of a same specification controlling for some time-varying households variables which are likely to increase the probability of defaulting on mortgage. Specifically, I control for the number of unemployed weeks of household head and household income. Nevertheless, the signs, statistical and economical significance of the variables of interest are either unchanged or strengthen.

Overall, the results suggest that different types of borrowers were affected differently as a result of increased supply of credit following the 2005 bankruptcy reform. On the one hand, high leverage households in higher exemption states (states where access to credit were more limited before the reform) received more credit and increased their expenditures while faces relatively no more financial distress. This suggest the increased availability of credit allowed high leverage households to better smooth their consumption. Note that even if we observed a relative rise of defaults among high leverage borrowers in high exemption states, we could not conclude that their choice of borrowing was necessarily suboptimal as high leverage borrowers are likely to be financialy constrained and a risky optimal borrowing might well end up in default. However, households with low education and those with self-control problems are unlikely to be financially constrained in the sense that their income is unlikely to grow and therefore their aggresive borrowing cannot be explained by consumption smoothing behavior. Therefore, the availability of credit for these two groups of borrowers is not unambigously welfare-improving.

Similar results are found when using a decline in food consumption as a measure of household distress (Table 11). Using food consumption also implies that despite no impact on high leveraged households, the bankruptcy reform brought about hardship among households with low education and those with self-control problems. Comparing a state with a zero exposure to a median state, food consumption for low educated families and households with selfcontrol problem decreased, on average, by $3.9 \%$ and $5.2 \%$ following the reform. ${ }^{1}$ Overall, while I cannot infer that

\footnotetext{
${ }^{1}$ Karlan and Zinman (2010) find that credit access in South Africa improved food consumption, whereas Melzer (2011) find the opposite in the
} 
improving credit access as a result of the tougher bankruptcy law after 2005 was welfare-destroying for households with low education and those with self-control problems, the results do suggest that the debt service burden imposed by borrowing inhibits their ability to keep their home and forces them to reduce expenditures on crucial items such as their food consumption.

To sum up, this paper sheds light on one mechanism through which the 2005 bankruptcy reform increased financial vulnerability of households. Due to significantly higher costs of the post-reform bankruptcy law and therefore increased ability of unsecured lenders' collecting on their loans, the supply of credit to high leveraged households as well as low educated and those with self-control problem increased substantially. Although this seems to be helping high leveraged households to smooth their consumption, low educated households and those without self-control took on excessively high amounts of debt and became much more vulnerable. This unsustainable debt burden together with a harsher bankruptcy law brought about by the reform increased financial distress among these groups of borrowers. This could also be thought as a support for Mann (2006), who argues that by making it difficult and complicated to file for bankruptcy, the 2005 bankruptcy Act is effectively encouraging predatory lending by credit card companies.

\section{Robustness}

\subsection{Did Interest Rates Decline?}

Although household leverage increased substantially following the reform, one might argue that this does not necessarily mean that household debt burden increased. It could be argued that the fact that creditors collect more effectively on their loans under the tighter and more expensive bankruptcy law after 2005 lowers the lending rate which in turn leads to greater consumer debt. Although the PSID does not provide data about interest rate on household unsecured debt, there is no evidence that interest rates on unsecured consumer credit-mainly credit card debt- decreased following the reform. Based on the Survey of Consumer Finances data, between 2004-2007, although the median card limit rose $21.4 \%$ percent (increased supply), the median interest rate on credit cards did not decline (Bucks et al. (2009)). In addition, Simkovic (2009) finds that although bankruptcies and credit card company losses decreased and credit card companies achieved record profits as a result of the reform, the cost to consumers of credit card debt actually increased. The fact that credit card industry is not price-competitive, i.e., prices do not respond to changes in costs, had been pointed out by researchers (see for example Ausubel (1991); Calem and Mester (1995); Knittel and Stango (2003); Calem et al. (2006)).

\subsection{Changes in Income, Employment and Housing Prices Following the Reform}

One concern with the identification strategy might be that states with higher exemption limits were hit harder during the crisis and the negative effect was disproportionately more on households with low education and those with selfcontrol problems. For example, if the size of housing bubble was higher in states with higher exemption limits, one would expect to see a larger distress in these states when the bubble burst. In this case, my estimated effects might simply be proxying for the severity of crisis rather than the impact of increased credit supply and excessive borrowing on household distress. As already shown in Table 4, there is no significant relation between the size of housing case of paydy lending in the US. 
price growth from 2000 to 2005 and exemption limits. That is, states with higher exemption limits did not have a significantly larger housing bubble.

Table 12 presents the impact of bankruptcy reform on households' inability to pay back their mortgage loans, controling for differential house price growth, income growth, and change in unemployment for households residing in states with different exemption limits. Specifically, I add three more control variables of the form (Post $x$ Exposure $x$ Interaction) where Interaction variables are house price change, income change, and unemployment change. As shown in Table 12 only house price growth is significant at $10 \%$ level. However, the estimates on my variables of interest remain economically and statistically significant. Similar results is obtained by looking at my other proxy for household distress, food consumption. Therefore, the results of this paper cannot be explained by differential changes in income, employment, or house price growth of low educated households or those with self-reported self-control problems who live in high exemption states.

\section{Conclusion}

In the past 30 years, financial innovation -especially the advent of credit cards- has allowed households to access more credit and thus consumer unsecured debt has risen substantially. Revealed preference logic says that this growth of debt should be welfare-improving: a consumer borrows only if she will benefit (weakly, in expectation). Some behavioral models, nonetheless, cast doubts: biases in preferences or cognition may lead consumers to over-borrow. For instance, Laibson et al. (Forthcoming) find that consumers with present-biased preferences would commit $\$ 2,000$ to not borrow on credit cards; Ausubel (1991) argues that over-optimism produces excess credit card borrowing, and Stango and Zinman (2009) show that consumers tend to underestimate the interest rate on short-term loans and borrow more expensively and heavily as a result. In this paper, I exploit the 2005 bankruptcy reform, which was a pro-creditor reform, and a Difference-in-Differences methodology to investigate how a shock to credit supply affects households borrowing and their financial hardship. First, I show that the reform caused a massive increase in the supply of unsecured consumer credit. While households with high leverage, low education, and those with selfcontrol problems responded more aggressively to this increased supply, only low educated households and those with self-control problem face a subsequent higher financial distress. This suggest that increased access to credit is not unambiguously welfare-improving for some groups of households. The reason why households with low education and those with self-control problem borrowed too much could be either because of their cognitive biases and lack of financial literacy so that they underestimated the costs associated with the fees, penalties and late payments on their credit cards, or because they ignored the substantial increased cost of bankruptcy and the fact that their unsecured debt will not be discharged as in pre- 2005 bankruptcy law. If the latter is the main cause, there will be less concern in the long-run in that once borrowers have learned that the bankruptcy rules have changed, they can be expected to reduce their demand for unsecured debt. However, if the excessive borrowing was due to cognitive biases or financial illiteracy, policymakers have a crucial role in decreasing financial distress among vulnerable households.

It should be stressed that there is no doubt that the changes in consumer credit market -financial innovations- and the resulted increased households' access to credit have created opportunities for households to smooth consumption over time, which should create net benefits for informed consumers even if they result in higher levels of bankruptcies. However, there might be other aspects to these changes in credit market: as borrowing options increase, poorly informed consumers could be encouraged to make poor credit choices. This is a key factor behind increased concern about possible predatory lending especially to groups with low levels of education and financial sophistication. There- 
fore, the policy reform that is likely to be beneficial should improve consumers ability to make informed borrowing decisions. This could be done by increasing financial education (Lusardi (2008)) and/or requiring credit card lenders to increase their minimum monthly payment levels so that debtors pay less interest and reduce their consumption before they accumulate too much debt. Another type of policy could be mandating disclosure of information in a form that enables people to overcome limitations or biases at the time of financial decision (Bertrand and Morse (2011)). For example, credit card lenders could be required to inform consumers each month how long it will take to repay their loans if they pay only the minimum amount or as proposed by Mann (2006), payment terminals for credit card transactions could be modified so that each time consumers use their credit cards, they would be told whether the purchase will trigger a penalty for exceeding the credit limit and how much interest they will pay if the purchase adds to their credit card debt. Nevertheless, the ideal form of the policy remains unclear. More empirical analysis and field experiments are needed to identify the regulatory response that balances the marginal costs and benefits of these policies.

\section{References}

Ai, C. and Norton, E. C. (2003). Interaction terms in logit and probit models, Economics Letters 80(1): 123-129.

Ausubel, L. M. (1991). The failure of competition in the credit card market, American Economic Review 81(1): 50-81.

Bar-Gill, O. (2004). Seduction by plastic, American Law \& Economics Association Annual Meetings 1013, American Law \& Economics Association.

Barron, J. M., Staten, M. E. and Wilshusen, S. M. (2002). The impact of casino gambling on personal bankruptcy filing rates, Contemporary Economic Policy 20(4): 440-455.

Berkowitz, J. and Hynes, R. (1999). Bankruptcy exemptions and the market for mortgage loans, Journal of Law and Economics 42(2): 809-30.

Bertaut, C. C. and Haliassos, M. (2006). Credit cards: Facts and theories, The Economics of Consumer Credit, MIT Press, Cambridge, MA.

Bertrand, M. and Morse, A. (2011). Information disclosure, cognitive biases, and payday borrowing, Journal of Finance 66(6): 1865-1893.

Bond, P., Musto, D. K. and Yilmaz, B. (2009). Predatory mortgage lending, Journal of Financial Economics 94(3): 412-427.

Bucks, B. K., Kennickell, A. B., Mach, T. L. and Moore, K. B. (2009). Changes in u.s. family finances from 2004 to 2007: evidence from the survey of consumer finances, Federal Reserve Bulletin .

Calem, P. S., Gordy, M. B. and Mester, L. J. (2006). Switching costs and adverse selection in the market for credit cards: New evidence, Journal of Banking \& Finance 30(6): 1653-1685.

Calem, P. S. and Mester, L. J. (1995). Consumer behavior and the stickiness of credit-card interest rates, American Economic Review 85(5): 1327-36.

Campbell, J. Y. (2006). Household finance, Journal of Finance 61(4): 1553-1604.

Carrell, S. E. and Zinman, J. (2008). In harm's way? payday loan access and military personnel performance, $F R B$ of Philadelphia Working Paper. 
CFA (2006). Credit card facts, Technical report, Consumer Federation of America.

Cochrane, J. H. (1991). A simple test of consumption insurance, Journal of Political Economy 99(5): 957-76.

DellaVigna, S. (2009). Psychology and economics: Evidence from the field, Journal of Economic Literature 47(2): $315-72$.

DellaVigna, S. and Paserman, M. D. (2005). Job search and impatience, Journal of Labor Economics 23(3): 527-588.

Domowitz, I. and Sartain, R. L. (1999). Determinants of the consumer bankruptcy decision, Journal of Finance 54(1): 403-420.

Eiling, E. (Forthcoming). Industry-specific human capital, idiosyncratic risk and the cross-section of expected stock returns, Journal of Finance .

Fan, W. and White, M. J. (2003). Personal bankruptcy and the level entrepreneurial activity, Journal of Law and Economics XLVI: 543-566.

Fay, S., Hurst, E. and White, M. J. (2002). The household bankruptcy decision, American Economic Review 92(3): 706-718.

Fudenberg, D. and Levine, D. K. (2006). A dual-self model of impulse control, The American Economic Review 96(5): pp. 1449-1476.

GAO (2006). Increased complexity in rates and fees heightens need for more effective disclosures to consumers, Technical report, United States Government Accountability Office.

Gropp, R., Scholz, J. K. and White, M. J. (1997). Personal bankruptcy and credit supply and demand, The Quarterly Journal of Economics 112(1): 217-51.

Gross, D. B. and Souleles, N. S. (2002a). Do liquidity constraints and interest rates matter for consumer behavior? evidence from credit card data, The Quarterly Journal of Economics 117(1): 149-185.

Gross, D. B. and Souleles, N. S. (2002b). An empirical analysis of personal bankruptcy and delinquency, Review of Financial Studies 15(1): 319-347.

Gross, T., Notowidigdo, M. J. and Wang, J. (2012). Liquidity constraints and consumer bankruptcy: Evidence from tax rebates, NBER Working Papers 17807, National Bureau of Economic Research, Inc.

Gruber, J. and Kszegi, B. (2001). Is addiction rational? theory and evidence, The Quarterly Journal of Economics 116(4): 1261-1303.

Gul, F. and Pesendorfer, W. (2001). Temptation and self-control, Econometrica 69(6): 1403-1435.

Gul, F. and Pesendorfer, W. (2004). Self-control and the theory of consumption, Econometrica 72(1): 119-158.

Harris, C. J. and Laibson, D. (2002). Hyperbolic discounting and consumption, in M. Dewatripont, L. P. Hansen and StephenTurnovsky (eds), Advances in Economics and Econometrics: Theory and Applications, Vol. 1, Eighth World Congress, pp. 258-298.

Heidhues, P. and Koszegi, B. (2010). Exploiting naivete about self-control in the credit market, American Economic Review 100(5): 2279-2303. 
Hynes, R. M., Malani, A. and Posner, E. A. (2004). The political economy of property exemption laws, Journal of Law and Economics 47(1): 19-43.

Johnson, S., Kotlikoff, L. J. and Samuelson, W. (2001). Can people compute? an experimental test of the life cycle consumption model, Essays on Saving, Bequests, Altruism, and Life-Cycle Planning, MIT Press, Boston.

Karlan, D. and Zinman, J. (2010). Expanding credit access: Using randomized supply decisions to estimate the impacts, Review of Financial Studies 23(1): 433-464.

Knittel, C. R. and Stango, V. (2003). Price ceilings as focal points for tacit collusion: Evidence from credit cards, American Economic Review 93(5): 1703-1729.

Laibson, D. (1997). Golden eggs and hyperbolic discounting, The Quarterly Journal of Economics 112(2): $443-77$.

Laibson, D., Repetto, A. and Tobacman, J. (2003). A debt puzzle, in P. Aghion, R. Frydman, J. Stiglitz and M. Woodford (eds), Knowledge, Information, and Expectations in Modern Economics: In Honor of Edmund S. Phelps, Princeton University Press, pp. 228-266.

Laibson, D., Repetto, A. and Tobacman, J. (Forthcoming). Estimating discount functions with consumption choices over the lifecycle, American Economic Review .

Lawless, R. M., Littwin, A. K., Porter, K. M., Pottow, J., Thorne, D. and Warren, E. (2008). Did bankruptcy reform fail? an empirical study of consumer debtors, American Bankruptcy Law Journal 82: 349-406.

Lefgren, L. and McIntyre, F. (2009). Explaining the puzzle of cross-state differences in bankruptcy rates, Journal of Law and Economics 52(2): 367-393.

Li, W., White, M. J. and Zhu, N. (2011). Did bankruptcy reform cause mortgage defaults to rise?, American Economic Journal: Economic Policy 3(4): 123-47.

Lusardi, A. (2008). Household saving behavior: The role of financial literacy, information, and financial education programs, NBER Working Papers 13824, National Bureau of Economic Research, Inc.

Lusardi, A. and Tufano, P. (2009). Debt literacy, financial experiences, and overindebtedness, NBER Working Papers 14808, National Bureau of Economic Research, Inc.

Mann, R. J. (2006). Bankruptcy reform and the 'sweat box' of credit card debt, University of Illinois Law Review .

McClure, S., Laibson, D., Loewenstein, G. and Cohen, J. (2004). Separate neural systems value immediate and delayed monetary rewards, Science 306: 503-07.

Meier, S. and Sprenger, C. (2010). Present-biased preferences and credit card borrowing, American Economic Journal: Applied Economics 2(1): 193-210.

Melzer, B. T. (2011). The real costs of credit access: Evidence from the payday lending market, The Quarterly Journal of Economics 126(1): 517-555.

Mian, A. and Sufi, A. (2011). What explains high unemployment? the aggregate demand channel, SSRN eLibrary .

Modigliani, F. (1986). Life cycle, individual thrift, and the wealth of nations, American Economic Review 76(3): 297313. 
Mookherjee, D. and Lilienfeld-Toal, U. v. (2011). How did the us housing slump begin? the role of the 2005 bankruptcy reform, Boston University - Department of Economics - Working Papers Series WP2011-033, Boston University - Department of Economics.

Morgan, D. P., Iverson, B. C. and Botsch, M. J. (2011). Subprime foreclosures and the 2005 bankruptcy reform, Economic Policy Review Forthcoming.

Morgan, D. P. and Strain, M. R. (2007). Payday holiday: how households fare after payday credit bans, Staff Reports 309, Federal Reserve Bank of New York.

Morse, A. (2011). Payday lenders: Heroes or villains?, Journal of Financial Economics 102(1): $28-44$.

NFCC (2006). Consumer counseling and education under bapcpa, Technical report, National Foundation for Credit Counseling.

O’Donoghue, T. and Rabin, M. (1999). Doing it now or later, The American Economic Review 89(1): pp. $103-124$.

O’Donoghue, T. and Rabin, M. (2007). Incentives and Self Control, Cambridge University Press, chapter 8, pp. 215245.

Simkovic, M. (2009). The effect of bapcpa on credit card industry profits and prices, American Bankruptcy Law Journal 83.

Skiba, P. M. and Tobacman, J. B. (2011). Do payday loans cause bankruptcy?, Working paper .

Stango, V. and Zinman, J. (2009). Exponential growth bias and household finance, Journal of Finance 64(6): 28072849.

Stango, V. and Zinman, J. (2011). Fuzzy math, disclosure regulation, and market outcomes: Evidence from truth-inlending reform, Review of Financial Studies 24(2): 506-534.

Sullivan, T., Warren, E. and Westbrook, J. L. (2000). The Fragile Middle Class: Americans in Debt, Yale University Press.

Thaler, R. (1981). Some empirical evidence on dynamic inconsistency, Economics Letters 8(3): 201-207.

URL: http://ideas.repec.org/a/eee/ecolet/v8y1981i3p201-207.html

White, M. J. (2007). Bankruptcy reform and credit cards, The Journal of Economic Perspectives 21(4): pp. 175-200.

White, M. J. (2008). Bankruptcy: Past puzzles, recent reforms, and the mortgage crisis, Working Paper 14549, National Bureau of Economic Research.

Zinman, J. (2010). Restricting consumer credit access: Household survey evidence on effects around the oregon rate cap, Journal of Banking \& Finance 34(3): 546-556. 
Table 1: States Home Equity Bankruptcy Exemptions and Median Home Prices, Sorted by Exemption

\begin{tabular}{lcclcc}
\hline State & Exemption & Home Price & State & Exemption & Home Price \\
\hline Maryland & 0 & 326 & Colorado & 45 & 231 \\
New Jersey & 0 & 362 & California & 50 & 485 \\
Pennsylvania & 0 & 162 & Delaware & 50 & 213 \\
Alabama & 5 & 136 & Idaho & 50 & 164 \\
Kentucky & 5 & 124 & New York & 50 & 284 \\
Ohio & 5 & 128 & Alaska & 54 & 204 \\
South Carolina & 5 & 158 & Connecticut & 75 & 313 \\
Tennessee & 5 & 144 & Mississippi & 75 & 124 \\
Virginia & 5 & 279 & Vermont & 75 & 182 \\
Illinois & 7.5 & 224 & North Dakota & 80 & 120 \\
Georgia & 10 & 152 & Montana & 100 & 156 \\
North Carolina & 10 & 160 & New Hampshire & 100 & 220 \\
Wyoming & 10 & 154 & Arizona & 150 & 256 \\
Nebraska & 12.5 & 128 & Minnesota & 200 & 188 \\
Indiana & 15 & 113 & Rhode Island & 200 & 280 \\
Missouri & 15 & 129 & Nevada & 350 & 327 \\
Hawaii & 20 & 496 & Massachusetts & 500 & 366 \\
Utah & 20 & 173 & Arkansas & Unlimited & 113 \\
Louisiana & 25 & 137 & Washington, D.C. & Unlimited & 391 \\
Oregon & 25 & 235 & Florida & Unlimited & 266 \\
West Virginia & 25 & 148 & Iowa & Unlimited & 123 \\
Michigan & 30 & 145 & Kansas & Unlimited & 137 \\
New Mexico & 30 & 165 & Oklahoma & Unlimited & 110 \\
Maine & 35 & 195 & South Dakota & Unlimited & 115 \\
Washington & 40 & 260 & Texas & Unlimited & 136 \\
Wisconsin & 40 & 161 & Median & 40 & 164 \\
\hline & & & & &
\end{tabular}

Notes: Exemptions are in thousands of dollars in 2005. Exemption is the dollar amount of home equity that unsecured lenders cannot claim under bankruptcy. House price is the median house price in a state in 2005. Data is taken from Morgan et al. (2011). 
Table 2: Summary Statistics, Full Sample

This table presents summary statistics for households participating in 2003 to 2009 waves of PSID as well as BAPCPA exposure measures. LogEx is the log of the homestead exemption limit measured in 2005. Unlimit is the dummy variable that gets values of 1 for states with unlimited homestead exemption, and zero otherwise. LogExMinS is another exposure measure which is the log of minimum of exemption limit and a state's median house price. Only data on foreclosures and food consumption includes information from the 2009 PSID survey, whereas other variables are taken from the 2003 to 2007 PSID surveys.

\begin{tabular}{lrrrr}
\hline Variable & Mean & Median & Sd & $\mathrm{N}$ \\
\hline Mortgage (in \$10,000) & 12.54 & 9.99 & 11.06 & 7,880 \\
Unsecured debt (in \$10,000) & 1.68 & 0.72 & 1.22 & 16,140 \\
Total debt (in \$10,000) & 9.99 & 6.42 & 7.64 & 16,140 \\
Income (in \$10,000) & 7.05 & 5.18 & 3.61 & 16,140 \\
Unsecured debt/income & 0.27 & 0.07 & 0.79 & 16,140 \\
Total debt/income & 1.23 & 0.57 & 0.94 & 16,140 \\
Secured debt/income & 0.98 & 0.52 & 0.67 & 16,140 \\
Ln (Medical care) & 6.22 & 6.25 & 1.50 & 16,132 \\
Ln (Utilities) & 6.78 & 7.09 & 2.43 & 16,140 \\
Ln (Transportation) & 6.18 & 6.79 & 2.04 & 16,138 \\
Ln (Apparel and recreation) & 7.17 & 7.60 & 2.07 & 16,140 \\
Ln (Furnishing) & 6.18 & 6.39 & 3.43 & 15,802 \\
Ln (Schooling) & 6.10 & 6.21 & 3.28 & 15,934 \\
Homeowner & 0.66 & 1.00 & 0.47 & 16,140 \\
House value (in \$100,000) & 2.26 & 1.62 & 2.38 & 10,481 \\
Married & 0.57 & 1.00 & 0.50 & 16,140 \\
Family size & 2.75 & 2.00 & 1.47 & 16,140 \\
Age (in 100) & 0.46 & 0.46 & 0.15 & 16,140 \\
Sex & 0.74 & 1.00 & 0.44 & 16,140 \\
White & 0.63 & 1.00 & 0.48 & 16,140 \\
Weeks unemployed & 0.63 & 0.00 & 3.96 & 16,140 \\
Own business & 0.11 & 0.00 & 0.31 & 16,140 \\
Education (in 100) & 0.13 & 0.12 & 0.03 & 16,140 \\
Self-control problem, 2004 & 0.06 & 0.00 & 0.22 & 5,380 \\
Foreclosure & 1.45 & 0.00 & 5.49 & 17,088 \\
Ln (food consumption) & 7.56 & 7.68 & 0.87 & 21,522 \\
LogEx & 2.21 & 2.18 & 1.96 & 5,380 \\
Unlimit & 0.17 & 0.00 & 0.37 & 5,380 \\
LogExMinS & 2.16 & 2.18 & 1.83 & 5,380 \\
\hline & & & &
\end{tabular}


Table 3: Summary Statistics, Pre- and Post- reform

This table presents summary statistics for households participating in 2003 to 2009 waves of PSID, divided to pre- versus post- reform. Only foreclosures and food consumption data include information from the 2009 survey.

\begin{tabular}{lcccc|cccc}
\hline Variable & Mean & Median & Sd & $\mathrm{N}$ & Mean & Median & Sd & $\mathrm{N}$ \\
\hline & \multicolumn{4}{c}{ Pre-reform } \\
\hline Homeowner & 0.66 & 1.00 & 0.48 & 10,761 & 0.68 & 1.00 & 0.47 & 5,379 \\
Mortgage(in \$10,000) & 11.99 & 9.31 & 10.47 & 10,761 & 13.61 & 10.19 & 12.07 & 5,379 \\
Unsecured debt (in \$10,000) & 1.56 & 0.67 & 1.13 & 10,761 & 1.93 & 0.77 & 1.11 & 5,379 \\
Total debt (in \$10,000) & 9.48 & 6.20 & 7.12 & 10,761 & 11.02 & 6.78 & 10.22 & 5,379 \\
Income (in \$10,000) & 6.98 & 5.21 & 3.27 & 10,761 & 7.49 & 4.82 & 4.15 & 5,379 \\
Unsecured debt/income & 0.23 & 0.05 & 0.76 & 10,761 & 0.37 & 0.10 & 0.80 & 5,379 \\
Total debt/income & 1.16 & 0.55 & 0.89 & 10,761 & 1.37 & 0.60 & 0.96 & 5,379 \\
Secured debt/income & 0.92 & 0.30 & 1.95 & 10,761 & 1.09 & 0.35 & 1.80 & 5,379 \\
Foreclosure (\%) & 0.54 & 0.00 & 7.31 & 8,544 & 2.10 & 0.00 & 14.32 & 8,544 \\
Ln(food consumption) & 7.61 & 7.67 & 0.86 & 10,761 & 7.52 & 7.61 & 0.87 & 10,761 \\
Weeks unemployed & 0.56 & 0.00 & 3.67 & 10,761 & 0.77 & 0.00 & 4.47 & 5,379 \\
\hline
\end{tabular}


Table 4:

Determinants of Exemption Limits

The dependent variable in the first two columns are the log of homestead exemption limits in 2005, and in the last two columns are the minimum of homestead exemption and median house price in a state. Homestead exemption limit for states with unlimited exemption level is set to $\$ 1,000,000$ in the first two columns. LogEx1975 is the log of states' exemption limits in 1975. House price growth from 2000Q2 to 2005Q2, used as a proxy for housing bubble, is taken from Office of Federal Housing Enterprise Oversight (OFHEO). Other state-level control variables are constructed using the 2005 PSID data. Values of t-statistics are in parentheses, where $* * *$ indicates significance at $1 \%$ level, $* *$ indicates significance at $5 \%$ level and * indicates significance at $10 \%$ level.

\begin{tabular}{|c|c|c|c|c|}
\hline Dependent Variable: & $\begin{array}{c}(1) \\
\log (\text { exemp })\end{array}$ & $\begin{array}{c}(2) \\
\log (\text { exemp) }\end{array}$ & $\begin{array}{c}(3) \\
\log (\text { exempMinS })\end{array}$ & $\begin{array}{c}(4) \\
\log (\text { exempMinS })\end{array}$ \\
\hline $\operatorname{lnExemp} 75$ & $\begin{array}{c}0.808 * * * \\
(9.43)\end{array}$ & & $\begin{array}{c}1.286 * * * \\
(6.58)\end{array}$ & \\
\hline Ln(Income) & $\begin{array}{l}-1.534 \\
(-1.04)\end{array}$ & $\begin{array}{l}3.245 \\
(1.26)\end{array}$ & $\begin{array}{l}-4.561 \\
(-1.35)\end{array}$ & $\begin{array}{l}3.044 \\
(0.65)\end{array}$ \\
\hline House price growth $2000-05$ & $\begin{array}{l}0.016 \\
(0.48)\end{array}$ & $\begin{array}{l}0.036 \\
(0.57)\end{array}$ & $\begin{array}{l}0.032 \\
(0.41)\end{array}$ & $\begin{array}{l}0.063 \\
(0.55)\end{array}$ \\
\hline Leverage & $\begin{array}{c}-0.053 \\
(-0.313)\end{array}$ & $\begin{array}{l}0.078 \\
(0.24)\end{array}$ & $\begin{array}{l}-0.092 \\
(-0.23)\end{array}$ & $\begin{array}{l}0.117 \\
(0.20)\end{array}$ \\
\hline Family size & $\begin{array}{c}0.999 * \\
(1.87)\end{array}$ & $\begin{array}{l}0.743 \\
(0.74)\end{array}$ & $\begin{array}{l}1.723 \\
(1.40)\end{array}$ & $\begin{array}{l}1.315 \\
(0.72)\end{array}$ \\
\hline Homeowner & $\begin{array}{l}-1.344 \\
(-0.89)\end{array}$ & $\begin{array}{l}3.108 \\
(1.17)\end{array}$ & $\begin{array}{l}-1.827 \\
(-0.53)\end{array}$ & $\begin{array}{l}5.257 \\
(1.09)\end{array}$ \\
\hline Interest rate & $\begin{array}{l}-0.294 \\
(-1.28)\end{array}$ & $\begin{array}{l}0.356 \\
(0.87)\end{array}$ & $\begin{array}{l}-0.568 \\
(-1.08)\end{array}$ & $\begin{array}{l}0.466 \\
(0.63)\end{array}$ \\
\hline Unemployment & $\begin{array}{c}0.549 * * \\
(2.20)\end{array}$ & $\begin{array}{l}0.805^{*} \\
(1.92)\end{array}$ & $\begin{array}{l}0.670 * \\
(1.90)\end{array}$ & $\begin{array}{l}0.620 \\
(0.88)\end{array}$ \\
\hline Have mortgage & $\begin{array}{l}-0.889 \\
(-0.58)\end{array}$ & $\begin{array}{l}-5.535 \\
(-1.06)\end{array}$ & $\begin{array}{l}-0.478 \\
(-0.13)\end{array}$ & $\begin{array}{l}-7.873 \\
(-1.61)\end{array}$ \\
\hline White & $\begin{array}{l}1.489 \\
(1.15)\end{array}$ & $\begin{array}{l}0.790 \\
(0.61)\end{array}$ & $\begin{array}{l}2.568 \\
(1.62)\end{array}$ & $\begin{array}{l}1.455 \\
(0.62)\end{array}$ \\
\hline Education & $\begin{array}{l}0.286 \\
(1.06)\end{array}$ & $\begin{array}{l}0.283 \\
(1.09)\end{array}$ & $\begin{array}{l}0.354 \\
(1.11)\end{array}$ & $\begin{array}{l}0.348 \\
(0.74)\end{array}$ \\
\hline Ln(Housevalue) & $\begin{array}{l}0.405 \\
(0.54)\end{array}$ & $\begin{array}{l}0.292 \\
(0.20)\end{array}$ & $\begin{array}{l}2.551 \\
(1.48)\end{array}$ & $\begin{array}{l}2.370 \\
(0.93)\end{array}$ \\
\hline Gini & $\begin{array}{c}-0.0863 \\
(-0.01)\end{array}$ & $\begin{array}{l}-7.598 \\
(-0.92)\end{array}$ & $\begin{array}{l}0.610 \\
(0.05)\end{array}$ & $\begin{array}{c}-11.301 \\
(-0.73)\end{array}$ \\
\hline Own business & $\begin{array}{l}-1.156 \\
(-0.85)\end{array}$ & $\begin{array}{l}-0.991 \\
(-0.39)\end{array}$ & $\begin{array}{l}-1.356 \\
(-0.43)\end{array}$ & $\begin{array}{l}-1.092 \\
(-0.23)\end{array}$ \\
\hline $\begin{array}{l}\text { Observations } \\
\text { R-squared }\end{array}$ & $\begin{array}{c}51 \\
0.76\end{array}$ & $\begin{array}{c}51 \\
0.15\end{array}$ & $\begin{array}{c}51 \\
0.62\end{array}$ & $\begin{array}{c}51 \\
0.14\end{array}$ \\
\hline
\end{tabular}


Table 5:

What Correlates with Self-control Problem Variable

The dependent variable is self-control problem, which gets 1 if the household's head believes he/she or his/her partner have problems managing their money and keeping track of their expenses. Smoker gets values of 1 if household head or his/her partner smoke cigarette. Own Business is a dummy for those who own business. Education is the years of education of household head. The data is from the 2005 PSID survey. Standard errors are clustered at the state level. Values of t-statistics are in parentheses, where *** indicates significance at $1 \%$ level, $* *$ indicates significance at $5 \%$ level and $*$ indicates significance at $10 \%$ level.

\begin{tabular}{lc}
\hline Dependent Variable: & $(1)$ \\
\hline Log (Unsecured debt) & $0.003^{* * *}$ \\
& $(3.10)$ \\
Log (Secured debt) & -0.001 \\
& $(-0.16)$ \\
Smoker & $0.002^{* * *}$ \\
& $(3.16)$ \\
Ln (income) & $-0.012^{*}$ \\
& $(-1.86)$ \\
Family size & $0.008^{*}$ \\
& $(1.83)$ \\
Age & 0.002 \\
Homeowner & $(1.14)$ \\
& -0.014 \\
Own business & $(-1.39)$ \\
Education & $-0.015^{*}$ \\
& $(-1.88)$ \\
Observations & -0.002 \\
R-squared & $(-1.52)$ \\
\hline
\end{tabular}


Table 6:

Bankruptcy Reform and Household Leverage

All regressions include time and household fixed effects. Post is a dummy variable which gets values of 1 after the reform and zero otherwise. Unlimit is a dummy variable which is one for states with unlimited exemption limits. The sample is from the Panel Study of Income Dynamics 2002-2006 working year. Values of t-statistics are in parentheses, where *** indicates significance at $1 \%$ level, ** indicates significance at 5\% level and $*$ indicates significance at $10 \%$ level.

\begin{tabular}{|c|c|c|c|c|c|c|}
\hline \multirow[t]{2}{*}{ Dependent variable: } & \multicolumn{3}{|c|}{ Unsecured debt-to-income } & \multicolumn{3}{|c|}{ Secured debt-to-income } \\
\hline & (1) & $(2)$ & (3) & (4) & (5) & (6) \\
\hline Exposure $\times$ Post & $\begin{array}{c}0.102 * * * \\
(3.44)\end{array}$ & $\begin{array}{c}0.119 * * \\
(2.15)\end{array}$ & $\begin{array}{c}0.110 * * * \\
(2.89)\end{array}$ & $\begin{array}{l}-0.022 \\
(-0.07)\end{array}$ & $\begin{array}{l}-0.073 \\
(-0.32)\end{array}$ & $\begin{array}{l}0.063 \\
(0.26)\end{array}$ \\
\hline Unlimit $\times$ Post & $\begin{array}{c}0.084^{*} \\
(1.88)\end{array}$ & & $\begin{array}{c}0.086^{*} \\
(1.80)\end{array}$ & $\begin{array}{l}-0.213 \\
(-0.68)\end{array}$ & & $\begin{array}{l}-0.186 \\
(-0.62)\end{array}$ \\
\hline Homeowner & & & $\begin{array}{l}-0.040 \\
(-1.32)\end{array}$ & & & $\begin{array}{c}0.843 * * * \\
(9.01)\end{array}$ \\
\hline Family size & & & $\begin{array}{c}0.030^{* *} \\
(2.12)\end{array}$ & & & $\begin{array}{c}-0.074^{*} \\
(-1.94)\end{array}$ \\
\hline Education & & & $\begin{array}{c}0.016^{*} \\
(1.89)\end{array}$ & & & $\begin{array}{l}0.024 \\
(0.17)\end{array}$ \\
\hline Weeks unemployed & & & $\begin{array}{l}0.001 \\
(0.04)\end{array}$ & & & $\begin{array}{l}-0.004 \\
(-0.17)\end{array}$ \\
\hline Observations & 16,140 & 16,140 & 16,140 & 16,140 & 16,140 & 16,140 \\
\hline R-squared & 0.335 & 0.325 & 0.337 & 0.166 & 0.166 & 0.170 \\
\hline Exposure & $\log E x$ & $\log$ ExMinS & $\log \mathrm{Ex}$ & $\log E x$ & $\log$ ExMinS & $\log E x$ \\
\hline Cluster & State & State & State & State & State & State \\
\hline Household FE & Yes & Yes & Yes & Yes & Yes & Yes \\
\hline Time FE & Yes & Yes & Yes & Yes & Yes & Yes \\
\hline
\end{tabular}


Table 7:

Bankruptcy Reform and Household Debt Levels

All regressions include time and household fixed effects. Post is a dummy variable which gets values of 1 after the reform and zero otherwise. Unlimit is a dummy variable which is one for states with unlimited exemption limits. The sample is from the Panel Study of Income Dynamics 2002-2006 working year. Values of t-statistics are in parentheses, where *** indicates significance at $1 \%$ level, ** indicates significance at 5\% level and $*$ indicates significance at $10 \%$ level.

\begin{tabular}{|c|c|c|c|c|c|c|}
\hline \multirow[t]{2}{*}{ Dependent variable: } & \multicolumn{3}{|c|}{ Log unsecured debt } & \multicolumn{3}{|c|}{ Log secured debt } \\
\hline & (1) & $(2)$ & (3) & (4) & (5) & (6) \\
\hline Exposure $\times$ Post & $\begin{array}{c}0.113 * * * \\
(3.38)\end{array}$ & $\begin{array}{c}0.118 * * * \\
(3.09)\end{array}$ & $\begin{array}{c}0.112 * * * \\
(3.25)\end{array}$ & $\begin{array}{l}0.043 \\
(1.20)\end{array}$ & $\begin{array}{l}-0.018 \\
(-0.67)\end{array}$ & $\begin{array}{l}-0.021 \\
(-1.28)\end{array}$ \\
\hline Unlimit $\times$ Post & $\begin{array}{c}0.069 * * \\
(2.11)\end{array}$ & & $\begin{array}{c}0.070^{*} \\
(1.91)\end{array}$ & $\begin{array}{l}0.147 \\
(0.52)\end{array}$ & & $\begin{array}{l}0.222 \\
(1.22)\end{array}$ \\
\hline Ln (income) & $\begin{array}{c}0.008 * \\
(1.88)\end{array}$ & $\begin{array}{c}0.009^{*} \\
(1.96)\end{array}$ & $\begin{array}{c}0.007^{*} \\
(1.83)\end{array}$ & $\begin{array}{c}0.012 * * * \\
(5.10)\end{array}$ & $\begin{array}{c}0.017 \text { *** } * \\
(5.04)\end{array}$ & $\begin{array}{c}0.014^{*} \\
(1.80)\end{array}$ \\
\hline Homeowner & & & $\begin{array}{l}0.021 \\
(0.12)\end{array}$ & & & $\begin{array}{c}6.091 * * * \\
(19.40)\end{array}$ \\
\hline Family size & & & $\begin{array}{c}0.101 * * \\
(2.08)\end{array}$ & & & $\begin{array}{c}0.145 * * * \\
(3.45)\end{array}$ \\
\hline Education & & & $\begin{array}{l}-0.155 \\
(-0.53)\end{array}$ & & & $\begin{array}{l}-0.586 \\
(-1.02)\end{array}$ \\
\hline Weeks unemployed & & & $\begin{array}{l}-0.004 \\
(-0.35)\end{array}$ & & & $\begin{array}{l}-0.007 \\
(-0.58)\end{array}$ \\
\hline Observations & 16,140 & 16,140 & 16,140 & 16,140 & 16,140 & 16,140 \\
\hline R-squared & 0.706 & 0.706 & 0.716 & 0.792 & 0.791 & 0.820 \\
\hline Exposure & $\log E x$ & $\log$ ExMinS & $\log E x$ & $\log E x$ & $\log$ ExMinS & $\log E x$ \\
\hline Cluster & State & State & State & State & State & State \\
\hline Household FE & Yes & Yes & Yes & Yes & Yes & Yes \\
\hline Time FE & Yes & Yes & Yes & Yes & Yes & Yes \\
\hline
\end{tabular}


Table 8:

Bankruptcy Reform and Household Leverage: Heterogeneous Effects

All regressions include time and household fixed effects. Post is a dummy variable which gets values of 1 after the reform and zero otherwise. Exposure measure used is LogExMinS. The sample is from the Panel Study of Income Dynamics 2002-2006 working year. Education is the household head's years of education. Leverage is households total debt over income. Income growth and Income volatility are the growth and volatility of labor income according to the industry of household's head and it is taken from Eiling (Forthcoming). Self-control problem is a dummy variable which gets 1 for those who self-report that they have difficulties tracking their expenses and managing their budget, and zero otherwise. Each regression includes all level variables as well as pairwise interaction, yet for brevity the table only reports the variables of interest. Values of $\mathrm{t}$-statistics are in parentheses, where $* * *$ indicates significance at $1 \%$ level, $* *$ indicates significance at $5 \%$ level and $*$ indicates significance at $10 \%$ level.

\begin{tabular}{|c|c|c|c|c|c|c|}
\hline \multirow[t]{4}{*}{ Dependent variable: } & \multicolumn{6}{|c|}{ Unsecured debt-to-income } \\
\hline & (1) & (2) & (3) & (4) & $(5)$ & (6) \\
\hline & Age, & Income & Income & Leverage, & Education, & Self-control \\
\hline & 2004 & Growth & Volatility & 2004 & 2004 & Problem, 2004 \\
\hline \multirow[t]{2}{*}{ Exposure $\times$ Post $\times$ Column title } & -0.021 & -0.004 & 0.003 & $0.027 * *$ & $-0.009 * *$ & $0.052 * * *$ \\
\hline & $(-1.39)$ & $(-0.24)$ & $(1.21)$ & $(2.13)$ & $(-2.33)$ & $(3.31)$ \\
\hline \multirow[t]{2}{*}{ Exposure $\times$ Post } & $0.132 * * *$ & $0.115^{* * *} *$ & $0.091 * *$ & $0.044 * *$ & $0.174 * * *$ & $0.096 * *$ \\
\hline & $(2.82)$ & $(2.74)$ & $(2.11)$ & $(2.24)$ & $(3.40)$ & $(2.18)$ \\
\hline Observations & 16,140 & 16,140 & 16,140 & 16,140 & 16,140 & 16140 \\
\hline R-squared & 0.335 & 0.310 & 0.315 & 0.319 & 0.315 & 0.316 \\
\hline Cluster & State & State & State & State & State & State \\
\hline Time FE & Yes & Yes & Yes & Yes & Yes & Yes \\
\hline Household FE & Yes & Yes & Yes & Yes & Yes & Yes \\
\hline
\end{tabular}


Table 9:

\section{Bankruptcy Reform and Expenses, by Household Type}

Every number in the table corresponds to a $\beta_{1}$ coming from a regression similar to Equation 3 where the dependent variable is the log of different expenditure categories. Post is a dummy variable which gets values of 1 after the reform and zero otherwise. Exposure measured used is LogExMinS. Education is a dummy for those with no high school diploma. Leverage is households' total debt over income. Income growth and Income volatility are the growth and volatility of labor income according to the industry of household's head and it is taken from Eiling (Forthcoming). Self-control problem is a dummy variable which gets 1 for those who self-report that they have difficulties tracking their expenses and managing their budget, and zero otherwise.Utility is the sum of electricity, gas, and water, and telephone expenses. School includes all school-related expenses such as purchase or rental of books, supplies, uniforms, or equipment including computers and software, tuition or tutoring (not including the amount expend for day care or nursery school). Furnishing includes all home repairs and household furnishing and equipments expenditures. Transportation includes bus and train fares as well as gasoline, parking, car insurance and repair expenditures. Clothing includes all expenses related to clothing and apparel, including footwear, outerwear, and products such as watches or jewelry. Vacation includes all expenses on trips and vacations, including transportation, accommodations as well as recreation and entertainment, including tickets to movies, sporting events, and performing arts and hobbies including exercise, bicycles, trailers, camping, photography, and reading materials. Medical care is the total of households out-of-pocket medical care costs. The sample is from the Panel Study of Income Dynamics 2002-2006 working year. Values of t-statistics are in parentheses, where $* * *$ indicates significance at $1 \%$ level, ** indicates significance at $5 \%$ level and * indicates significance at $10 \%$ level.

\begin{tabular}{|c|c|c|c|c|c|c|}
\hline Dependent variable: & $\begin{array}{c}\text { (1) } \\
\text { Utility }\end{array}$ & $\begin{array}{c}\text { (2) } \\
\text { Furnishing }\end{array}$ & $\begin{array}{c}\text { (3) } \\
\text { Schooling }\end{array}$ & $\begin{array}{c}(4) \\
\text { Transportation }\end{array}$ & $\begin{array}{c}\text { (5) } \\
\text { Apparel \& } \\
\text { Recreation }\end{array}$ & $\begin{array}{c}(6) \\
\text { Medical } \\
\text { Care }\end{array}$ \\
\hline Exposure $\times$ Post $\times$ Age, 2004 & $\begin{array}{l}0.021 \\
(0.83)\end{array}$ & $\begin{array}{l}0.005 \\
(1.05)\end{array}$ & $\begin{array}{l}0.001 \\
(0.05)\end{array}$ & $\begin{array}{l}-0.016 \\
(-0.59)\end{array}$ & $\begin{array}{l}0.001 \\
(0.53)\end{array}$ & $\begin{array}{l}-0.041 \\
(-0.96)\end{array}$ \\
\hline Exposure $\times$ Post $\times$ Income growth & $\begin{array}{l}0.001 \\
(1.13)\end{array}$ & $\begin{array}{l}0.025 \\
(1.15)\end{array}$ & $\begin{array}{l}-0.021 \\
(-0.02)\end{array}$ & $\begin{array}{l}-0.005 \\
(-0.59)\end{array}$ & $\begin{array}{l}-0.009 \\
(-1.23)\end{array}$ & $\begin{array}{l}0.024 \\
(0.89)\end{array}$ \\
\hline Exposure $\times$ Post $\times$ Income volatility & $\begin{array}{l}0.010 \\
(0.31)\end{array}$ & $\begin{array}{l}-0.095 \\
(-1.00)\end{array}$ & $\begin{array}{c}0.043 \\
(0.003)\end{array}$ & $\begin{array}{l}-0.003 \\
(-0.26)\end{array}$ & $\begin{array}{l}0.001 \\
(0.23)\end{array}$ & $\begin{array}{l}0.041 \\
(0.65)\end{array}$ \\
\hline Exposure $\times$ Post $\times$ Leverage, 2004 & $\begin{array}{l}0.004 \\
(0.33)\end{array}$ & $\begin{array}{l}0.015^{*} \\
(1.90)\end{array}$ & $\begin{array}{l}0.012 \\
(1.15)\end{array}$ & $\begin{array}{l}-0.005 \\
(-0.59)\end{array}$ & $\begin{array}{l}0.011 \\
(1.11)\end{array}$ & $\begin{array}{c}0.034 * * \\
(2.22)\end{array}$ \\
\hline Exposure $\times$ Post $\times$ Education, 2004 & $\begin{array}{l}0.014 \\
(1.52)\end{array}$ & $\begin{array}{c}0.025 * * \\
(2.09)\end{array}$ & $\begin{array}{l}-0.071 \\
(-0.96)\end{array}$ & $\begin{array}{l}-0.005 \\
(-0.59)\end{array}$ & $\begin{array}{c}0.041^{* * * *} \\
(3.13)\end{array}$ & $\begin{array}{l}0.019 \\
(1.19)\end{array}$ \\
\hline Exposure $\times$ Post $\times$ Self-control Prob & $\begin{array}{l}0.002 \\
(1.42)\end{array}$ & $\begin{array}{l}0.012 * \\
(1.86)\end{array}$ & $\begin{array}{l}-0.021 \\
(-1.10)\end{array}$ & $\begin{array}{l}-0.005 \\
(-0.59)\end{array}$ & $\begin{array}{c}0.051 * * \\
(2.23)\end{array}$ & $\begin{array}{l}-0.009 \\
(-0.99)\end{array}$ \\
\hline $\begin{array}{l}\text { Observations } \\
\text { Cluster } \\
\text { Time FE } \\
\text { Household FE }\end{array}$ & $\begin{array}{c}16,140 \\
\text { State } \\
\text { Yes } \\
\text { Yes }\end{array}$ & $\begin{array}{c}15,802 \\
\text { State } \\
\text { Yes } \\
\text { Yes }\end{array}$ & $\begin{array}{c}15934 \\
\text { State } \\
\text { Yes } \\
\text { Yes }\end{array}$ & $\begin{array}{l}16,138 \\
\text { State } \\
\text { Yes } \\
\text { Yes }\end{array}$ & $\begin{array}{c}16,140 \\
\text { State } \\
\text { Yes } \\
\text { Yes }\end{array}$ & $\begin{array}{c}16,132 \\
\text { State } \\
\text { Yes } \\
\text { Yes }\end{array}$ \\
\hline
\end{tabular}


Table 10:

Bankruptcy Reform, Household Leverage, and Defaults

The table presents the estimates from a linear probability model where the dependent variable is a binary variable which gets 1 if a household receives foreclosure filings in the corresponding year and zero otherwise. Post is the post-reform dummy which gets 1 for all years after 2005 and zero otherwise. Exposure is measured as LogExMinS (see Section 4). Leverage is total debt over income. Self-control problem is one for households who self-report they have problem managing their money and cannot keep track their expenses and zero otherwise. Low education is a dummy which gets one for those with no high school diploma. The sample is restricted to PSID homeowners who have mortgage on their home and it is from 2002 to 2008 . Values of t-statistics are in parentheses, where $* * *$ indicates significance at $1 \%$ level, ** indicates significance at 5\% level and * indicates significance at $10 \%$ level.

\begin{tabular}{lccc}
\hline Panel A & \multicolumn{2}{c}{ Dependent variable: Foreclosure-start? } \\
\cline { 2 - 4 } & $(1)$ & $(2)$ & $(3)$ \\
& $\begin{array}{c}\text { Leverage } \\
\text { Low education, }\end{array}$ & $\begin{array}{c}\text { Self-control } \\
\text { problem, } 2004\end{array}$ \\
\hline \multirow{2}{*}{ Post $\times$ Exposure $\times$ Column Title } & 0.001 & $0.004^{* *}$ & $0.006^{* * *}$ \\
& $(1.23)$ & $(2.11)$ & $(3.32)$ \\
Post $\times$ Exposure & $0.003^{* *}$ & $0.001^{*}$ & $0.002^{* *}$ \\
& $(2.13)$ & $(1.83)$ & $(2.19)$ \\
& & & \\
\hline Panel B & Dependent variable: Foreclosure-start? \\
\cline { 2 - 4 } Post $\times$ Exposure $\times$ Column Title & 0.009 & $0.003^{* *}$ & $0.006^{* * *}$ \\
Post $\times$ Exposure & $(1.05)$ & $(2.07)$ & $(4.02)$ \\
Weeks unemployed & $0.004^{* *}$ & $0.001^{*}$ & $0.002^{* *}$ \\
Log(income) & $(2.09)$ & $(1.87)$ & $(2.09)$ \\
& 0.001 & 0.002 & 0.003 \\
Observations & $(1.23)$ & $(1.46)$ & $(1.36)$ \\
Time FE & $-0.005^{*}$ & $-0.004^{*}$ & $-0.005^{* *}$ \\
Household FE & $(-1.92)$ & $(-1.88)$ & $(-2.15)$ \\
Cluster & & & \\
\hline & 17,088 & 17,088 & 17,088 \\
& Yes & Yes & Yes \\
& Yes & Yes & Yes \\
& State & State & State \\
\hline
\end{tabular}


Table 11:

Bankruptcy Reform, Household Leverage, and Food Consumption

The table presents the estimates of fixed effect regression where the dependent variable is the log of food consumption. Food consumption is the sum of food at home, eaten outside, and food stamps. Post is the post-reform dummy which gets 1 for all years after 2005 and zero otherwise. Exposure is measured as LogExMinS (see Section 4). Leverage is total debt over income. Self-control problem is one for households who self-report they have problem managing their money and cannot keep track their expenses and zero otherwise. Low education is a dummy which gets one for those with no high school diploma. The data is from the PSID and spans from 2002 to 2008 working years. Values of t-statistics are in parentheses, where $* * *$ indicates significance at $1 \%$ level, $* *$ indicates significance at $5 \%$ level and * indicates significance at $10 \%$ level.

\begin{tabular}{lccc}
\hline Panel A & \multicolumn{2}{c}{ Dependent variable: Ln (Food consumption) } \\
\cline { 2 - 4 } & $(1)$ & $(2)$ & $(3)$ \\
& Leverage & Low education, & Self-control \\
& 2004 & 2004 & problem, 2004 \\
\hline \multirow{2}{*}{ Post $\times$ Exposure $\times$ Column Title } & 0.012 & $-0.018^{* * *}$ & $-0.024^{* * *}$ \\
& $(1.52)$ & $(-3.11)$ & $(-3.32)$ \\
Post $\times$ Exposure & $-0.024^{* * *}$ & $-0.009^{*}$ & $-0.015^{* *}$ \\
& $(-3.13)$ & $(-1.89)$ & $(-2.35)$ \\
& & & \\
\hline Panel B & Dependent variable: Ln (Food consumption) \\
\cline { 2 - 4 } Post $\times$ Exposure $\times$ Column Title & 0.015 & $-0.017^{* * *}$ & $-0.028^{* *}$ \\
Post $\times$ Exposure & $(1.05)$ & $(-2.87)$ & $(-2.19)$ \\
Weeks unemployed & $-0.023^{* *}$ & -0.007 & $-0.013^{* *}$ \\
Log $($ income) & $(-2.09)$ & $(-1.55)$ & $(-2.21)$ \\
Family size & -0.002 & $-0.001 *$ & -0.003 \\
& $(-1.03)$ & $(-1.89)$ & $(-1.36)$ \\
Observations & $0.005^{* *}$ & $0.004^{*}$ & $0.005^{*}$ \\
Hime FE & $(2.22)$ & $(1.88)$ & $(1.92)$ \\
Cluster & $0.002^{* *}$ & $0.005^{*}$ & $0.004^{* *}$ \\
\hline & $(2.01)$ & $(1.94)$ & $(2.19)$ \\
& & & \\
& 21,522 & 21,522 & 21,522 \\
& Yes & Yes & Yes \\
& Yes & Yes & State \\
\hline
\end{tabular}


Table 12:

Robustness Check - Bankruptcy Reform, Household Leverage and Defaults

The table presents the estimates from a linear probability model where the dependent variable is a binary variable which gets 1 if a household receives foreclosure filings in the corresponding year and zero otherwise. Post is the post-reform dummy which gets 1 for all years after 2005 and zero otherwise. Exposure is measured as LogExMinS (see Section 4). Leverage is total debt over income. Self-control problem is one for households who self-report they have problem managing their money and cannot keep track their expenses and zero otherwise. Low education is a dummy which gets one for those with no high school diploma. The sample is restricted to PSID homeowners who have mortgage on their home and it is from 2002 to 2008 . Values of t-statistics are in parentheses, where *** indicates significance at $1 \%$ level, ** indicates significance at 5\% level and * indicates significance at $10 \%$ level.

\begin{tabular}{lccc}
\hline Dependent variable: & \multicolumn{3}{c}{ Foreclosure-start? } \\
\cline { 2 - 4 } & $(1)$ & $(2)$ & $(3)$ \\
& $\begin{array}{c}\text { Leverage, } \\
\text { Low education, }\end{array}$ & $\begin{array}{c}\text { Self-control } \\
\text { problem, 2004 }\end{array}$ \\
\hline \multirow{2}{*}{ Post $\times$ Exposure $\times$ Column Title } & -0.001 & $0.002^{* *}$ & $0.004^{* * *}$ \\
Post $\times$ Exposure & $(-0.87)$ & $(2.09)$ & $(3.15)$ \\
Post $\times$ Exposure $\times$ House price growth & $0.002^{* *}$ & 0.001 & $0.001^{*}$ \\
& $(2.23)$ & $(1.33)$ & $(1.89)$ \\
Post $\times$ Exposure $\times$ Income growth & $-0.002^{*}$ & $-0.001 *$ & $-0.002^{* *}$ \\
Post $\times$ Exposure $\times$ Weeks unemployed & $(-1.84)$ & $(-1.92)$ & $(-2.12)$ \\
& 0.004 & 0.001 & 0.002 \\
Observations & $(1.09)$ & $(1.27)$ & $(1.49)$ \\
Time FE & -0.001 & -0.000 & -0.002 \\
Household FE & $(-1.23)$ & $(-1.46)$ & $(-1.36)$ \\
Cluster & & & 17,088 \\
\hline
\end{tabular}


Figure 1: Quarterly filings for bankruptcy

This figure plots the quarterly number of personal bankruptcy filings in the US. The vertical line shows the time when most of the provisions of the 2005 bankruptcy reform Act (BAPCPA) went into effect. The data is from American Bankruptcy Institute.

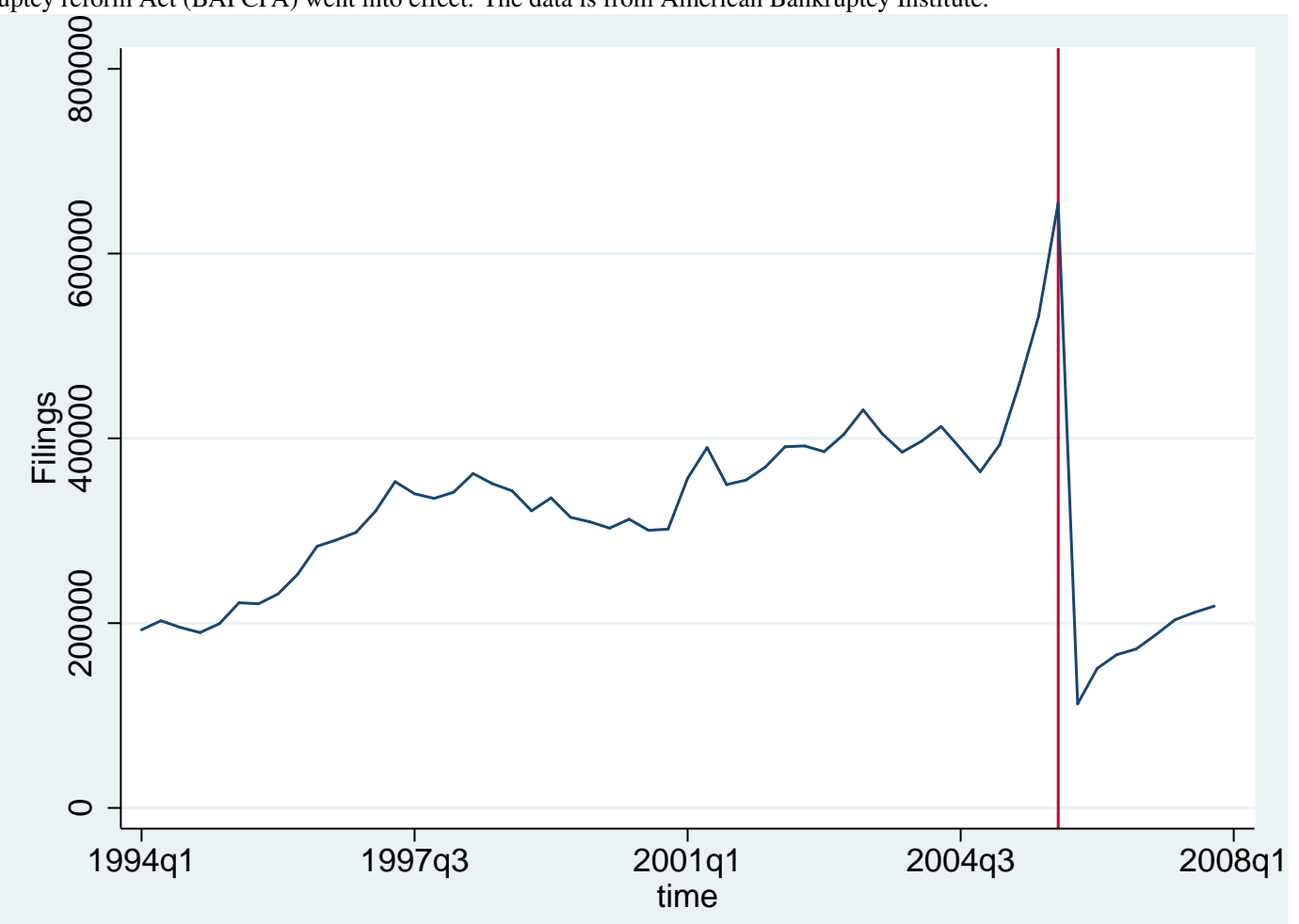


Figure 2: Growth of different types of debt

This figure presents the growth of mortgage and revolving debt in the U.S. About $98 \%$ of revolving debt is credit card debt. The vertical line shows the time of bankruptcy reform. The data comes from Board of Governors of the Federal Reserve System.

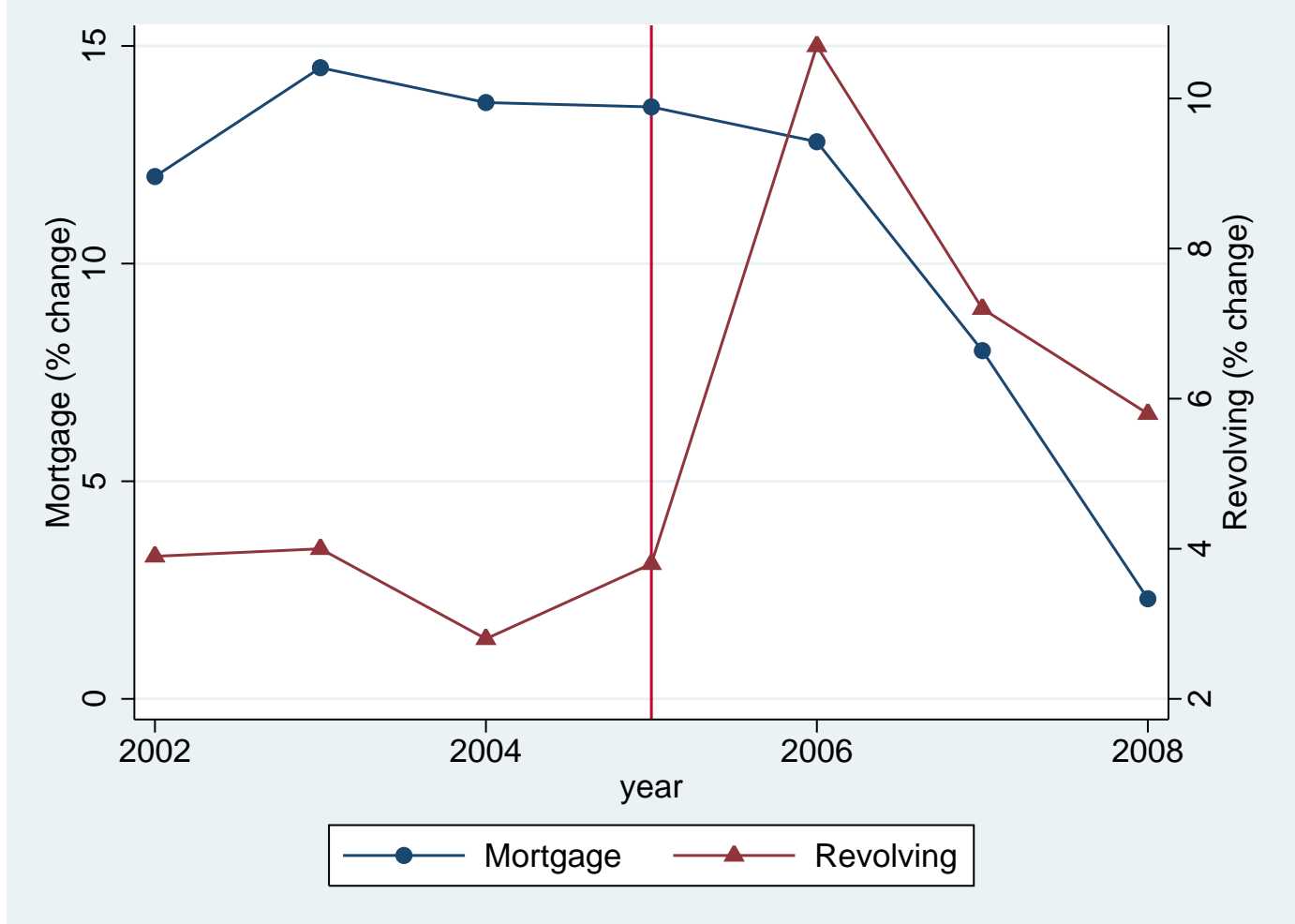


Figure 3: Debt Growth and Household Leverage, by Type of Debt

The figure shows the growth of households' different types of debt: secured and unsecured debt. The data is from Panel Study of Income and Dynamics (PSID).

\section{The growth of different types of debt}

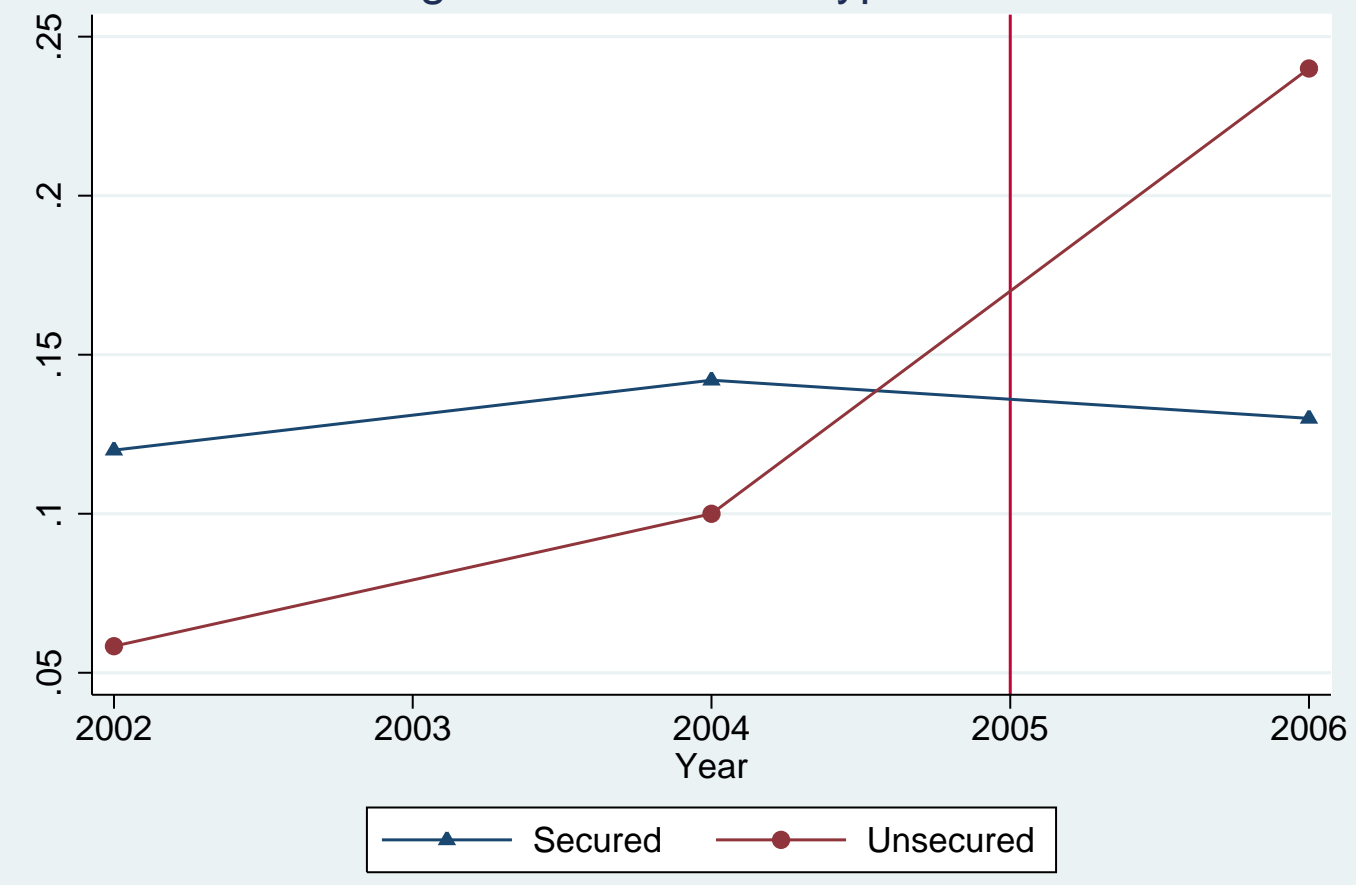


Figure 4: Bankruptcy Reform and Unsecured Debt-to-Income Ratio, by Exemption Limits

The figure plots household leverage as measured by unsecured debt-to-income from 2000 to 2008 for states with low vs high exemption limits. Low exemption states are constructed as those in the first quartile of 2005 homestead exemption limits, whereas high exemption states are those in the fourth quartile of 2005 homestead exemption limits. The vertical line shows the time of bankruptcy reform. The data on income and debt is from Panel Study of Income and Dynamics (PSID).

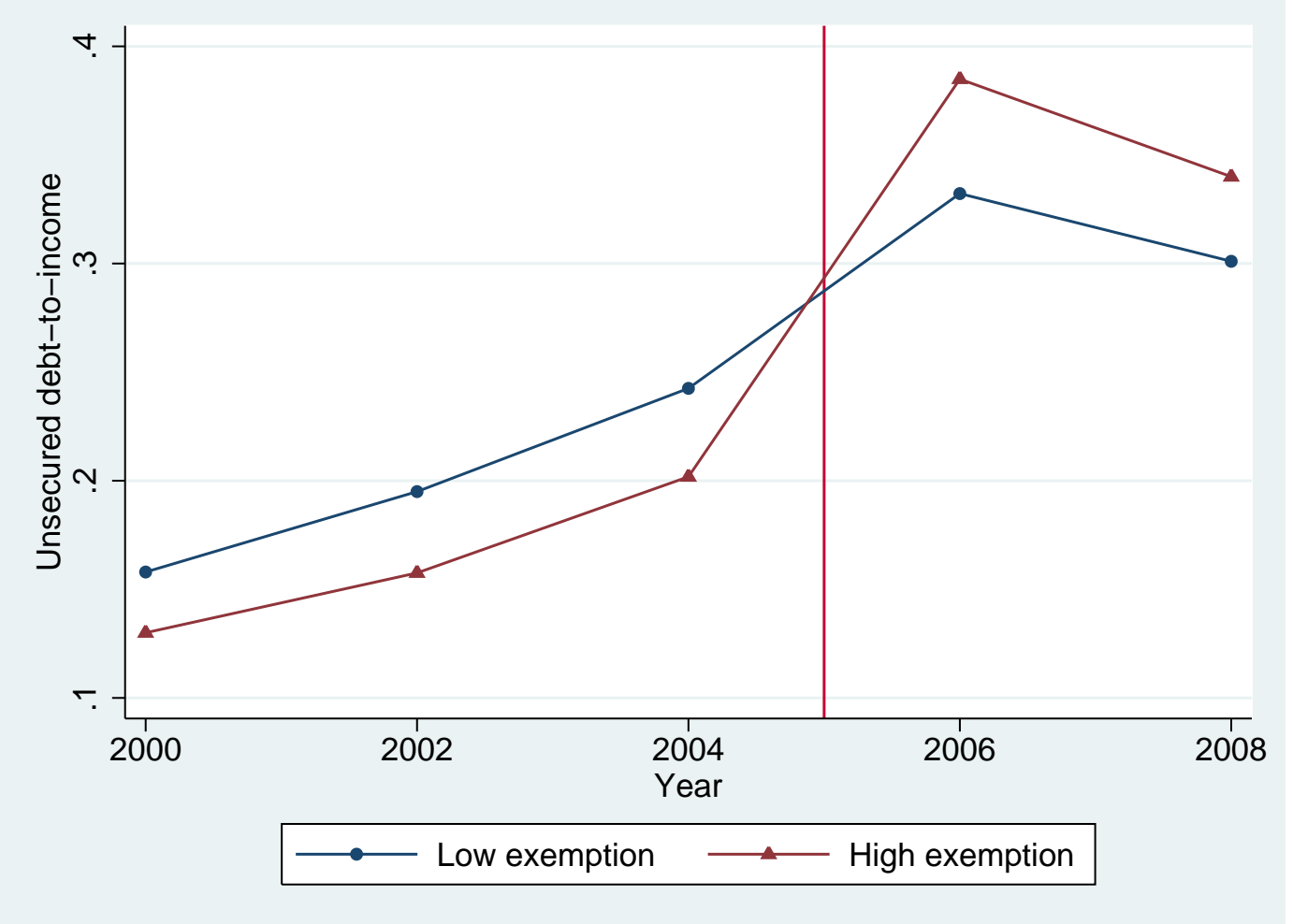


Figure 5: Default Patterns, by Exemption Limits and Household Types

Low exemption states are constructed as those in the first quartile of exposure, whereas high exemption states are those in the fourth quartile of exposure to the reform. The vertical line shows the time of bankruptcy reform. The data is from Panel Study of Income and Dynamics (PSID).

(a) All Homeowners

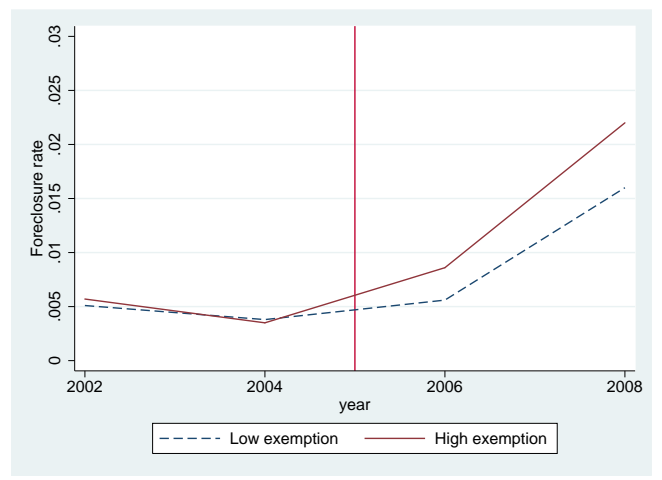

(b) Low leverage, 2004

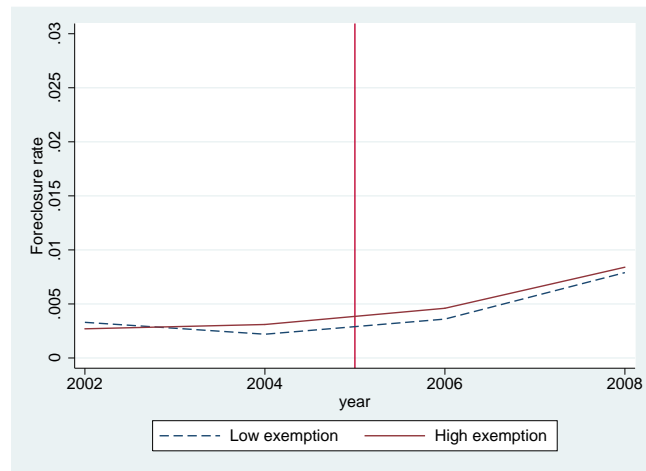

(d) High education

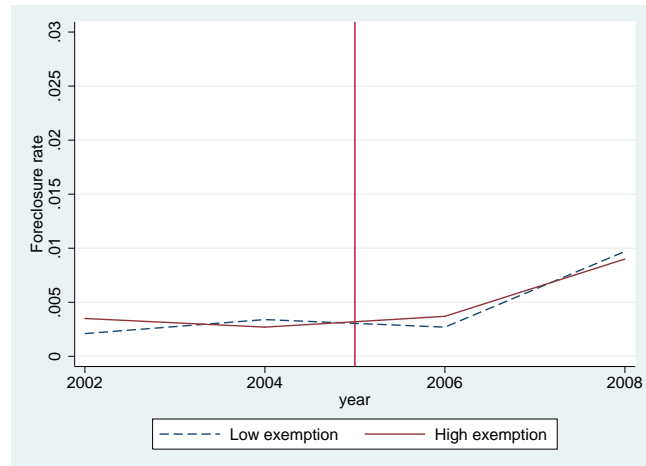

(f) With self-control

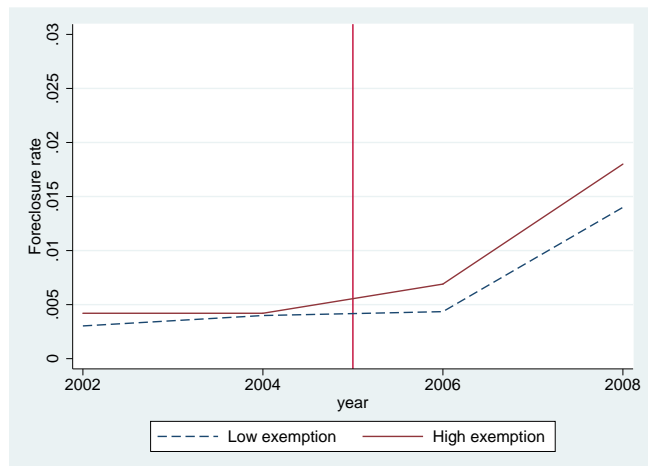

(c) High leverage, 2004

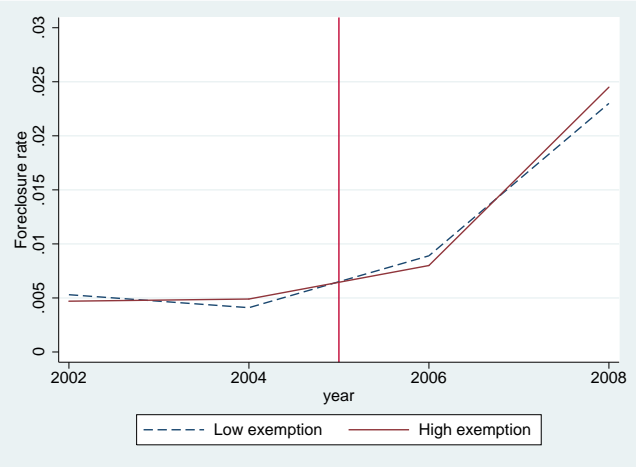

(e) Low education

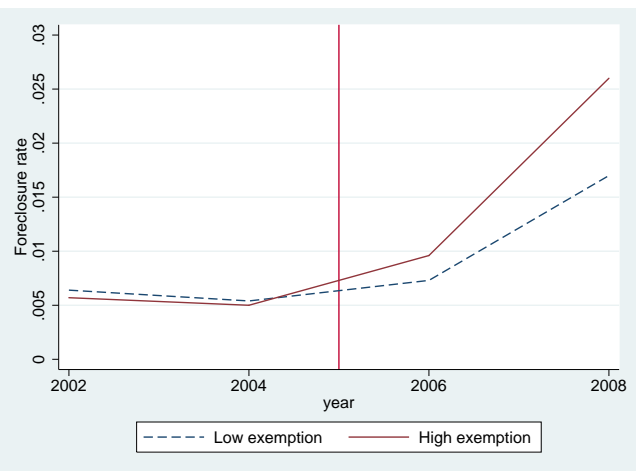

(g) Limited self-control

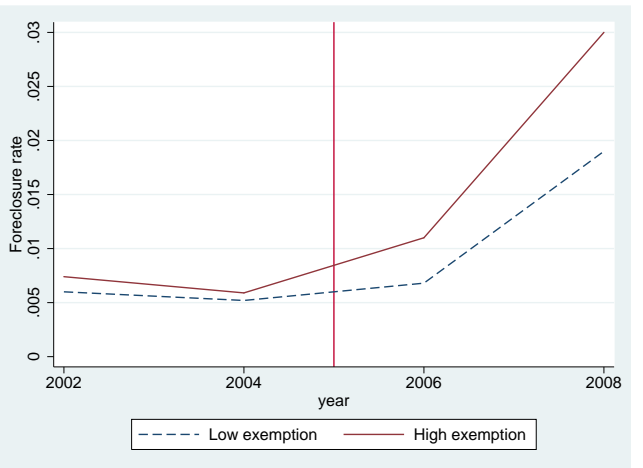

